\title{
A Survey of Biomedical Design Projects to Inform Skill Development in a New Undergraduate Biomedical Engineering Curriculum
}

\section{Ms. Kelsey Nicole Warren, Kansas State University}

Kelsey Warren is pursuing a B.S. in Biomedical Engineering from Kansas State University, Manhattan, KS. Her interests include biomedical engineering education, leadership training, and hands-on design as a learning modality for K-12 and post-secondary education. Ms. Warren is a member of the American Society for Engineering Education (ASEE) and the IEEE Engineering in Medicine and Biology Society (EMBS).

\section{Dr. Charles Carlson, Kansas State University}

Charles Carlson received a B.S. degree in physics from Fort Hays State University in 2013, and B.S., M.S., and Ph.D. degrees in electrical engineering (EE) from Kansas State University (KSU) in 2013, 2015, and 2019, respectively. In 2015, from January to July, he was an engineer at Black \& Veatch in Kansas City. He is currently a Teaching Assistant Professor in the KSU Department of Electrical and Computer Engineering. Dr. Carlson is interested in engineering education, biotechnology, and bioinstrumentation. $\mathrm{He}$ is a member of the American Society for Engineering Education (ASEE) the IEEE Engineering in Medicine and Biology Society.

\section{Dr. Steve Warren, Kansas State University}

Steve Warren received a B.S. and M.S. in Electrical Engineering from Kansas State University (KSU) in 1989 and 1991, respectively, followed by a Ph.D. in Electrical Engineering from The University of Texas at Austin in 1994. Dr. Warren is a Professor in the KSU Department of Electrical \& Computer Engineering, and he serves as the Program Coordinator for the KSU Undergraduate Biomedical Engineering Degree Program. Prior to joining KSU in August 1999, Dr. Warren was a Principal Member of the Technical Staff at Sandia National Laboratories in Albuquerque, NM. He directs the KSU Medical Component Design Laboratory, a facility partially funded by the National Science Foundation that provides resources for the research and development of distributed medical monitoring technologies and learning tools that support biomedical contexts. His research focuses on (1) plug-and-play, point-of-care medical monitoring systems that utilize interoperability standards, (2) wearable sensors and signal processing techniques for the determination of human and animal physiological status, and (3) educational tools and techniques that maximize learning and student interest. Dr. Warren is a member of the American Society for Engineering Education and the Institute of Electrical and Electronics Engineers. 


\title{
A Survey of Biomedical Design Projects to Inform Skill Development in a New Undergraduate Biomedical Engineering Curriculum
}

\begin{abstract}
Hands-on design projects are widely used in engineering curricula to improve hardware/software skills, develop design mindsets, and tie real-world problems to engineering curricula with an eye toward increased student engagement and retention. In Fall 2018, Kansas State University (KSU) accepted its first cadre of incoming freshmen into a new Biomedical Engineering (BME) degree program. In an effort to increase the effectiveness of the program's design courses, which will be offered annually to students of various ages beginning in Fall 2020, the authors performed a search of recent engineering education literature related to the inclusion of design projects in undergraduate BME curricula, focusing on (a) projects that could be reasonably incorporated into courses that support undergraduate students with little-to-no design experience, (b) efforts that map to the emphasis areas for this new BME program, (c) student-learning assessment techniques that have proved useful in these hands-on contexts, and (d) projects that would make interesting recruiting examples for high school students considering such a program. The overall goal of this work is to allow lessons learned from these earlier efforts to inform projects offered as part of this new BME curriculum. This paper presents (1) an overview of this new curriculum, (2) the skillsets that this new BME program intentionally addresses and the courses that will support that skillset development, (3) BME project-based efforts described in the literature that relate thematically to the emphasis areas in this curriculum, (4) assessment methods that have appeared useful when applied to such projects, and (5) suitable categories of starter projects for this new curriculum, including those that can be prototyped prior to the Fall 2020/2021 onset of the initial junior/senior-level design sequences.
\end{abstract}

\section{Introduction}

\section{A. Motivation and Goal}

A new Kansas State University (KSU) undergraduate Biomedical Engineering (BME) degree program was approved by the Kansas Board of Regents in June 2016 [1]-[3], and the first incoming cadre of freshman joined this program in Fall 2018. This program, partially spurred by demand from prospective students and their families, (a) strengthens the preexisting biomedical teaching/research synergy in the KSU College of Engineering, (b) attracts new students who might not otherwise have enrolled at KSU and/or in an engineering curriculum, (c) increases tuition revenue, and (d) helps to provide a pipeline of engineering talent for the growing Midwest U.S. biomedical industry. Consistent with similar, well-established BME programs nationwide, this program incorporates substantive hands-on design, as this learning format is known to (1) improve student engagement and retention [4]-[8] and (2) develop an engineering mindset and the hardware/software skillsets essential for success in industry [9], [10]. This intentional skillset development is especially important in BME curricula, as these skills help to remedy the breadth versus depth challenge faced by all BME programs [11]. That is, the need to address a broad collection of curricular topics bears the risk that specific topics and their requisite skillsets will not be covered in much depth unless they are explicitly singled out for emphasis. In other words, skill development in some areas may not well occur unless those skills are intentionally built into 
the curricular foundation, and these skills make students useful to employers and therefore hirable.

Some of the design elements embedded in the first instantiation of this undergraduate curriculum begin in Fall 2020/2021, at which point the first cohort of KSU BME students will engage in their two-semester junior/senior design experiences. To help prepare for these experiences, the authors thought it sensible to perform an early search of recent ( 2008 and newer) engineering education literature focused on design projects supported by undergraduate BME curricula. The goal is to use lessons learned from earlier hands-on design efforts to guide the BME curriculum committee in their choice of projects and educational venues that map to the learning outcomes and skillsets emphasized in this BME curriculum. Such projects should be suited for undergraduate students with little-to-no design experience and preferably be appropriate thematic matches to the emphasis areas in the degree program. Further, project elements should align well with effective student-learning assessment methods. Ideally, these projects should also be interesting by nature to potential incoming students so that the projects can serve as program recruiting mechanisms.

\section{B. Paper Contents}

This paper takes a two-pronged approach to address undergraduate design in the context of this

new biomedical engineering curriculum. First, Section II addresses the courses that comprise this curriculum and identifies the specific courses targeted for the development of specific skills. Second, Sections III and IV lay out the literature review approach/results and offer thoughts based on the results of that survey, where the restated goal is to allow published lessons learned from earlier undergraduate BME design efforts to inform projects offered as part of this new KSU BME curriculum. An appendix presents a tabular listing of these academic papers and some of their descriptors.

\section{Overview of the New Kansas State University Biomedical Engineering Curriculum}

The Kansas State University (KSU) Biomedical Engineering (BME) curriculum (128 credit hours) incorporates core courses (102 credit hours - see Figure 1) coupled with technical electives (26 credit hours - see Figure 2), where the latter comprise an area of emphasis [1]-[3]. Every student in the program takes the core courses, but technical electives vary depending on a student's chosen emphasis area and career path. For example, the BME core courses, when coupled with the required technical electives for an emphasis area (see the next section) and 9 credit hours of properly chosen discretionary technical electives (e.g., CHM 550 \& $532-$ Organic Chemistry II plus a lab (5 hours); BIOL 455 - General Microbiology with a lab (4 hours)), flesh out the courses required for entrance into nearby medical schools. Up to 13 hours of additional courses are suggested as preparatory courses for the Medical College Admission Test (MCAT) [12].

The following sections briefly describe these core courses, the emphasis areas, and the skills addressed in specific classes. Overarching program outcomes and areas of knowledge development can be found in the original curriculum proposal submitted to the Kansas Board of Regents [1]. 


\section{A. Curriculum Description}

Core Courses and Credits. The four curricular cores amount to 102 credit hours. Core courses address subject matter that the affiliated KSU faculty consider essential to a BME curriculum, regardless of a student's area of emphasis. High-level descriptions of these cores follow:

1. Math \& Science Core (52 credit hours) - This core consists of math, physics, statistics, and chemistry courses typical of an ABET-accredited engineering program [13], [14]. Additional courses in organic chemistry, biology, and human anatomy/physiology have been added to strengthen the backgrounds of these students in preparation for their upcoming BME courses and their subsequent career paths.

2. Biomedical Engineering Core (36 credit hours) - These core courses, consistent with model programs across the U.S., address a range of subjects relevant to biomedical engineering (refer to [1] for a representative topic listing). It is impossible to offer one generic curriculum that prepares students for all biomedical engineering topical areas at a suitable level of depth. As a partial solution, the BME core curriculum incorporates courses that address cross-cutting subject matter intended to strengthen each student's knowledge base with regard to a number of topical areas:

- Biomedical engineering (BME 001, 200) - Application areas, research, and career opportunities in biomedical engineering.

- Biomaterials (BME 430) - Interactions between materials and biological systems, techniques to assess biomaterial characteristics, and the role of biomaterial selection in the design of medical devices.

- Biomechanics (BME 451) - The mechanics of biological tissues and systems at the macroscopic scale. This course addresses the structure and mechanics of biological tissue based on the principles of statics and dynamics.

- Biomedical signals and instrumentation (ECE 512, ECE 540, and ECE 772/3) Signals that describe physiological processes, instrumentation to acquire those signals from human and animal subjects, and means to process those data.

- Clinical systems (BME 575) - Biomedical "systems of systems" in health care scenarios, including hospitals, home care settings, and ambulatory environments. Material focuses on "clinical engineering" subjects, emphasizing institutional implementation, training, ethics, design standards, and interoperability.

- Medical imaging (BME 674 and ECE 772/3) - Medical imaging modalities as an extension of biomedical instrumentation. Methods for image data acquisition, processing, and display form the core for these courses, which also address industry standards for image storage and transmission.

The Biomedical Engineering Core supports two two-semester design sequences, intended to produce graduates who can think through complex design challenges. Design courses in the junior year are more scripted, whereas design courses in the senior year are more open-ended. A sophomore-level design course, where each student engages in a design effort mapped to each emphasis area, is being considered consistent with the model adopted by the University of Wisconsin-Madison [15], [16].

3. Communication Core (8 credit hours) - This core involves oral/written communication courses taken by all students in the KSU College of Engineering.

4. Humanities \& Social Sciences Core (6 credit hours) - This core represents a 6-hour block of humanities and social sciences credit typical for departments within the KSU College of Engineering. 


\begin{tabular}{|llrl|}
\hline MATH \& SCIENCE CORE & Credits & Semester \\
\hline MATH 220 & Analytical Geometry and Calculus I & 4 & $\mathrm{FSSu}$ \\
MATH 221 & Analytical Geometry and Calculus II & 4 & $\mathrm{FSSu}$ \\
MATH 222 & Analytical Geometry and Calculus III & 4 & $\mathrm{FSSu}$ \\
MATH 240 & Elementary Differential Equations & 4 & $\mathrm{FSSu}$ \\
PHYS 213 & Engineering Physics I & 5 & $\mathrm{FS}$ \\
PHYS 214 & Engineering Physics II & 5 & $\mathrm{FS}$ \\
STAT 510 & Introductory Probability and Statistics I & 3 & $\mathrm{FS}$ \\
CHM 210 & Chemistry I & 4 & $\mathrm{FSSu}$ \\
CHM 230 & Chemistry II & 4 & $\mathrm{FSSu}$ \\
CHM 531 & Organic Chemistry I & 3 & $\mathrm{FS}$ \\
BIOL 198 & Principles of Biology & 4 & $\mathrm{FSSu}$ \\
BIOL 341 & Human Body I & 4 & $\mathrm{FS}$ \\
BIOL 342 & Human Body II & 4 & $\mathrm{FS}$ \\
& & $\mathbf{5 2}$ & \\
\hline
\end{tabular}

${ }^{\ominus}$ Or KIN 360 - Anatomy \& Physiology (8 credits, FS) instead of BIOL 341 \& 342

\begin{tabular}{|c|c|c|c|}
\hline \multicolumn{2}{|c|}{ BIOMEDICAL ENGINEERING CORE } & \multirow{2}{*}{$\begin{array}{r}\text { Credits } \\
0\end{array}$} & \multirow{2}{*}{$\begin{array}{l}\text { Semester } \\
\mathrm{F}\end{array}$} \\
\hline BME 001 & New Student Assembly & & \\
\hline BME 200 & Introduction to Biomedical Engineering & 3 & $\mathrm{~F}$ \\
\hline BME 430 & Biomaterials & 3 & $\mathrm{~F}$ \\
\hline BME 451 & Biomechanical Engineering & 3 & S \\
\hline BME 490/491 & Undergraduate BME Design Experience I/II & 3 & FS \\
\hline BME 575 & Clinical Systems Engineering & 3 & $S$ \\
\hline BME 590/591 & Senior Design Experience I/II & 5 & FS \\
\hline BME 674 & Medical Imaging & 3 & $S$ \\
\hline CIS 200 & Programming Fundamentals & 4 & FS \\
\hline ECE 512 & Linear Systems & 3 & FS \\
\hline ECE 540 & Applied Scientific Computing for Engineers & 3 & FS \\
\hline \multirow[t]{2}{*}{ ECE 772/3 } & Theory \& Techniques of Bioinstrumentation Lecture/Lab & 3 & \multirow[t]{2}{*}{$\mathrm{F}$} \\
\hline & Sub-Total Credit Hours & 36 & \\
\hline \multicolumn{2}{|c|}{ COMMUNICATION CORE } & Credits & Semester \\
\hline ENGL 100 & Expository Writing 1 & 3 & FS \\
\hline ENGL 415 & Written Communication for Engineers & 3 & FSSu \\
\hline \multirow[t]{2}{*}{ COMM 105} & Public Speaking $1 \mathrm{~A}$ & 2 & \multirow[t]{2}{*}{ FSSu } \\
\hline & Sub-Total Credit Hours & 8 & \\
\hline \multicolumn{2}{|c|}{ HUMANITIES \& SOCIAL SCIENCES CORE } & Credits & Semester \\
\hline \multirow[t]{3}{*}{ KIN $110^{\diamond \diamond}$} & Introduction to Public Health & 3 & FS \\
\hline & H\&SS Elective & 3 & \\
\hline & Sub-Total Credit Hours & 6 & \\
\hline
\end{tabular}

${ }^{\diamond}$ Or ECON 110 - Principles of Macroeconomics (3, FSSu)

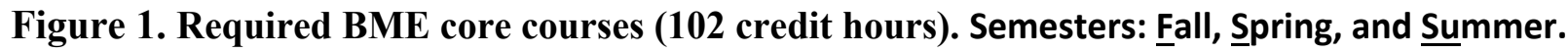


Emphasis Areas. The KSU BME curriculum currently supports two emphasis areas:

"Biomedical Sensors and Devices" and "Biomedical Computation" - see Figure 2. Each area of emphasis defines a set of required technical electives that every student must take plus a set of discretionary technical electives that depend on student career goals, e.g., in the case of a premedicine student, as noted earlier. Additional emphasis areas are being considered, e.g., "Tissue Engineering" and "Biomechanics," consistent with the literature search table in the appendix.

\begin{tabular}{|c|c|c|c|}
\hline \multicolumn{2}{|c|}{ AREA OF EMPHASIS: BIOMEDICAL SENSORS \& DEVICES } & \multirow{2}{*}{$\begin{array}{r}\text { Credits } \\
3\end{array}$} & \multirow{2}{*}{$\begin{array}{l}\text { Semester } \\
\text { FS }\end{array}$} \\
\hline ECE 210 & Introduction to Electrical Engineering & & \\
\hline ECE 241 & Introduction to Computer Engineering & 3 & FS \\
\hline ECE 431 & Microcontrollers & 3 & FS \\
\hline ECE 410 & Circuit Theory I & 3 & FS \\
\hline ECE 511 & Circuit Theory II & 3 & FS \\
\hline \multirow[t]{3}{*}{ ECE 647} & Digital Filtering & 3 & $\mathrm{~F}$ \\
\hline & Additional Technical Electives & 8 & \\
\hline & Sub-Total Credit Hours & 26 & \\
\hline
\end{tabular}

\begin{tabular}{|llrl|}
\hline AREA OF EMPHASIS: BIOMEDICAL COMPUTATION & Credits & Semester \\
\hline ECE 241 & Introduction to Computer Engineering & 3 & FS \\
CIS 300 & Data and Program Structures & 3 & FS \\
ECE 431 & Microcontrollers & 3 & FS \\
ECE 519 & Electric Circuits and Controls & 4 & FSS \\
CIS 501 & Software Architecture and Design & 3 & FS \\
ECE 670000 & Engineering Applications of Machine Intelligence & 3 & $\mathrm{~S}$ \\
& Additional Technical Electives $\quad$ Sub-Total Credit Hours & $\mathbf{2 6}$ & \\
& & $\mathbf{2 6}$ & \\
\hline
\end{tabular}

${ }^{000}$ Or ECE 771 - Control Theory Applied to Bioengineering (3 credits, S)

${ }^{00}$ Or CIS 730 - Principles of Artificial Intelligence (3 credits, S)

${ }^{000}$ Or CIS 732 - Machine Learning and Pattern Recognition (3 credits, F)

Figure 2. Emphasis areas (26 credit hours each).

Target Skills. High-level skills to be possessed by each graduate of the KSU BME program include the ability to

- apply calculus-based mathematics when analyzing and designing physical systems,

- statistically describe medical data and hardware/software system performance,

- quantify and report tissue movement,

- operate biomedical instruments and medical imaging systems,

- analyze biomedical data in the space, time, and frequency domains,

- develop software to control devices and to process biomedical data, 
- pursue a component- or system-level biomedical design based on an understanding of customer requirements and resource availability,

- lay out a medical "system of systems" comprised of commercially available hardware and software that utilize industry interoperability standards, and

- demonstrate professional skills centered around an understanding of personality profiles and an ability to communicate effectively in oral and written form.

More specific skillsets relate to the following areas, where supporting courses are noted in parentheses (core courses carry a normal font, whereas emphasis-area courses are in italics):

- written/oral communication (ENGL 100, COMM 105, ENGL 415, BME 200, BME 490/491, BME 590/591, ECE 772/773),

- hardware (ECE 210, ECE 241, ECE 431, BME 490/491, BME 590/591, ECE 772/773),

- software-C/C++/MATLAB/other (CIS 200, ECE 241, CIS 300, ECE 431, BME 451, CIS 501, BME 490/491, BME 590/591, ECE 647, ECE 670, BME 674, ECE 512, ECE 540, ECE 772/773),

- benchtop/portable/virtual instrumentation (PHYS 213/214, ECE 210, ECE 241, ECE 410, BME 451, BME 490/491, BME 590/591, ECE 772/773),

- time- and frequency-domain signal processing (BME 451, BME 490/491, BME 590/591, ECE 512, ECE 540, ECE 647, ECE 772/773),

- image processing (BME 674),

- statistical analyses (STAT 510, BME 451, BME 490/491, BME 590/591, BME 674, ECE 540),

- feature extraction/classification (BME 674, ECE 512, ECE 647, ECE 670, ECE 772/773),

- printed circuit board population (ECE 772/773),

- 3D modeling/printing (BME 490/491, BME 590/591, ECE 772/773),

- laboratory skills (CHM 210/230, BIOL 198, ECE 210, ECE 241, BME 430, BME 451, BME 490/491, BME 590/591, ECE 772/773), and

- wet lab skills and sterile techniques (BIOL 198, BIOL 341/342, BME 430, BME 451, BME 490/491, BME 590/591).

Hands-on design plays a role in many of these courses, including courses labeled as 'lecture' or 'recitation' because they have an accompanying laboratory, hardware, and/or software component. Note that BME 490/491 (junior-level design) and BME 590/590 (senior-level design) address various skills by nature, so these design sequences provide a suitable match for the types of hands-on BME courses addressed in this literature search (see the next section). The emphasis on software skills is intentional and arguably atypical in comparison with other BME curricula. First, this investment in programming abilities helps to address breadth versus depth issues faced by many BME curricula, where finding jobs for BME graduates can be a challenge because the graduates do not have a large-enough skill base in any one area to be attractive to employers. Second, the ability to create and use software is essential in the current healthcare enterprise, where electronic medical records are now standard, and an increasing number of medical devices interact with smartphones. 


\section{Literature Review}

As noted in the Abstract and in Section I.A, a search of recent engineering education literature was performed to identify hands-on design efforts previously supported by undergraduate Biomedical Engineering (BME) curricula. The goal is to allow lessons learned from prior design efforts to inform upcoming design experiences offered as part of the new KSU BME degree program [1]-[3], a program whose courses and target skillsets were laid out in Section II. Because these projects will be interspersed throughout nearly the entirety of the undergraduate BME curriculum, projects of interest for this literature search should be well suited for undergraduate students with minimal design experience and should provide a sensible thematic match for the emphasis areas in the degree program. Further, project experiences should map well to time-tested, student-learning assessment methods, and these projects should display the potential to serve as effective recruiting mechanisms for prospective BME students.

The resources employed for this search included Google [17], Google Scholar [18], IEEE Xplore [19], ASEE PEER [20], bound issues of the Journal of Engineering Education [21], the ASEE Computers in Education Journal [22], and Transactions on Techniques in STEM Education (ASEE Midwest conference papers), plus various bound proceedings for the annual conferences of the American Society for Engineering Education [23] and the IEEE Engineering in Medicine and Biology Society [24]. Search keywords included variants on the following terms: undergraduate, biomedical, design, project, hands-on, laboratory, device, build, sophomore, retention, and medical instrumentation. The initial search range was constrained to papers newer than 2007 to limit the number of overall papers and to increase the likelihood that these design efforts would employ modern engineering education tools.

\section{Results and Discussion}

The annotated bibliography resulting from these efforts archived the following information for each source: author(s), year, title, level (e.g., high school, freshman, sophomore, ...), rating (a 1to-5-star rating depending on its perceived value), technical design area, emphasis area (i.e., the closest KSU BME emphasis area), description (short synopsis of the work), student skills (skills fostered by the design experience), assessment method(s) (approach(es) used to quantify student learning), funding (grant or source that supported the work, if available), notes (commentary related to the item), and the host institution. Citation information was simultaneously tracked using the online Zotero reference manager software [25].

A subset of the annotated bibliography that resulted from these efforts is attached in tabular form as Appendix $A$ to the end of this document (after the References section). A few themes are of note in this appendix. First, as enumerated in Table 1 below, most of the projects relate to the "Sensors and Devices" emphasis area: 77 out of the 90 cited papers in Appendix A relate to at least one project involving sensors and/or device design. The "Computation" emphasis area came in second, represented by 21 out of 90 papers. The "Tissue Engineering" and "Biomechanics" emphasis areas garnered 19 and 7 papers, respectively. Given that most projects which involve biomechanics, computation, or tissue engineering also involve some form of a 
sensor or device, it is not surprising that a large number of projects fall within the "sensors and devices" area. Additionally, biomedical instrumentation has been an area of study for so long (e.g., when compared to a relatively new area such as tissue engineering) that a greater relative weight in terms of the number of educational sensors and devices efforts is not surprising.

Target students range in age from high school students (e.g., who attended summer courses/camps) up to seniors in college engaged in capstone design efforts. A large number of papers cited in the literature review were geared toward sophomore-to-senior-level students, whereas fewer were aimed at freshmen and high school students. This result may have been influenced by the fact that many freshmen and high school courses attempt to address multiple topics at a limited depth rather than focus on a single emphasis area, as a means to give the students an overview of the field.

Assessment approaches identified in the publications vary but generally reside in one or more of the following five categories (see the rightmost column in the summary table in Appendix A):

1. direct student feedback in the form of end-of-project surveys, pre/post surveys, and other student self-assessments (including interviews with students, and student focus groups),

2. quantitative assessments based on project/laboratory notebooks, write-ups, papers, reports and/or assignments (including pre/post laboratory exercises and questions), often guided by a formal rubric,

3. student presentations and/or demonstrations, including peer/instructor evaluations, some based on over-the-shoulder observations,

4. quizzes/exams, and

5. time reports and general activity/participation.

The relative frequencies of selected assessment types are tallied in Table 1, where the predominant assessment mechanism relates to student feedback in the form of surveys, interviews, and focus groups. Note that there is not a one-to-one correspondence between these overall assessment counts and the corresponding publications. Some efforts map to multiple types of assessment, and others involve none. In publications where education assessment methods are unidentified, a learning assessment (a) may have been performed but not noted or (b) may not have been performed because it was considered irrelevant, e.g., in a situation where the only goal was to summarize the technical aspects of a design experience or to produce a concept demonstration as a prototypical effort. Finally, no particular correlation is observable between different assessment categories and certain types of subject matter, institutions, or educational venues. 
Table 1. Paper counts related to the emphasis areas, the target student ages, and the assessment methods employed.

\begin{tabular}{|c|c|c|c|}
\hline Emphasis Area & Paper Count & Assessment Method & Paper Count \\
\hline Sensors and Devices & 77 & \multirow{7}{*}{$\begin{array}{l}\text { Direct Student Feedback } \\
\text { Surveys } \\
\text { Pre/Post Surveys } \\
\text { Other Self Assessments } \\
\text { Quantitative Assessments } \\
\text { Notebooks, Reports, Write- } \\
\text { Ups, or Papers } \\
\text { Assignments or Pre/Post } \\
\text { Lab Questions/Exercises }\end{array}$} & \\
\hline Computation & 21 & & 25 \\
\hline Tissue Engineering & 19 & & 24 \\
\hline Biomechanics & 7 & & 25 \\
\hline & & & \\
\hline Target Age & Paper Count & & 24 \\
\hline High School & 5 & & 6 \\
\hline Freshmen & 20 & $\begin{array}{l}\text { Presentations, Demonstrations, } \\
\text { or Evaluations }\end{array}$ & 18 \\
\hline Sophomore & 30 & Quizzes or Exams & 16 \\
\hline Junior & 29 & Activity or Participation & 2 \\
\hline Senior & 32 & None Listed & 31 \\
\hline Unspecified & 22 & & \\
\hline
\end{tabular}

One of the primary goals of the authors is to use these survey results to identify suitable project themes for Fall 2020 implementation and beyond, with the goal to realize some of these projects early so that the prototypes can be used in Summer 2020 to recruit new freshmen into the program. One can reasonably assume that a topic area occurs more frequently in the appendix because it garners more relative interest on behalf of faculty and students involved in the various efforts. Given that assumption, the following thematic areas appear promising:

- cardiac signal acquisition, processing, and parameter extraction,

- hand/foot prostheses,

- projects that integrate 3D printing,

- physiological process simulation,

- medical imaging, and

- tissue growth and bioreactor design.

With regard to the junior design sequence (BME 490/491), one of the goals of this course sequence is to help students develop technical skills that they can use later in their senior design team projects. An overview and tutorial for each of several software platforms (e.g., Excel, LabVIEW, MATLAB, and COMSOL) will be covered. In addition to completing tutorials, students will step through scripted exercises to help them become familiar with various facets and capabilities of these software packages that make these tools so useful when solving engineering problems. As an example, a cardiac signal acquisition module (one of the thematic areas noted above) could task each student with collecting their electrocardiogram using a bioamplifier and a National Instruments data acquisition unit controlled by a LabVIEW virtual instrument. A related module covering MATLAB could have a student create and analyze functions to modify and extract information from their collected ECGs. 
Finally, in addition to the subject areas addressed in the literature, experience dictates that students are also interested in design projects related to the following application scenarios:

- assistive technology for those with cognitive and physical disabilities,

- tools for other vulnerable populations, including infants and aging individuals,

- wearable devices and telemedicine,

- technologies for tissue replacement/enhancement,

- games that incorporate biosignal acquisition and feedback,

- designs for animals, especially companion animals,

- medical technology for under-resourced and developing environments,

- health care resources for first responders, disaster response, and battlefield medicine, and

- wellness capabilities for reduced-gravity environments.

These types of application scenarios can provide context for hands-on design projects and drive student interest by providing clarity in terms of societal benefits that can be achieved via the realization of such designs.

\section{Conclusions}

Hands-on design projects have been broadly employed in biomedical engineering programs to increase student engagement, learning, and retention. This paper addressed the layout of a new undergraduate Biomedical Engineering (BME) degree program at Kansas State University. This curriculum is designed to develop student skills within hands-on learning contexts - skills that will make these graduates hireable. To that end, the paper additionally addressed the results of a literature search related to undergraduate design projects in biomedical engineering curricula, where the goal was to find published results from earlier efforts that could inform hands-on design projects to be employed in courses supported by this new BME degree program. A subset of the resulting papers ( $\sim 100$ journal articles and conference papers) are summarized in tabular form as an appendix at the end of this document. These papers relate to projects intended for high school students up to seniors in college, and the projects address a number of subject areas germane to the emphasis areas supported by this new BME program.

\section{Acknowledgements}

The authors acknowledge the KSU Department of Electrical and Computer Engineering for providing undergraduate research funding in support of this endeavor.

\section{References}

[1] "New Undergraduate Biomedical Engineering Degree Program in the Kansas State University College of Engineering," Jun. 2016, https://www.kstate.edu/facsen/facsenate/2017/documents/121316_Attachment_3_BS_in_Biomedical_E ngineering.pdf.

[2] "Biomedical Engineering Program, Kansas State University Department of Electrical \& Computer Engineering," 2020, https://www.ece.k-state.edu/undergraduate/biomedical/.

[3] "K-State Biomedical Engineering," 2020, https://indd.adobe.com/view/82e40eee-7e3a4644-b5d7-05d635561da3. 
[4] D. W. Bixby. Product Training for the Technical Expert: The Art of Developing and Delivering Hands-On Learning, Wiley-IEEE Press, 2018.

[5] V. Lara-Prieto, J. de la Cruz-Hinojosa, E. J. Arrambide-Leal, F. Palomera-Palacios, M. I. Ruiz-Cantisani, and J. M. Campos-Sandoval. "First-year Engineering Students Engagement by Hands-on Experience with Star Wars Robotics," IEEE Global Engineering Education Conference (EDUCON), Dubai, United Arab Emirates, Apr. 2019, pp. 552-556, doi: 10.1109/EDUCON.2019.8725168.

[6] C. Carlson, G. Peterson, and D. Day. "Utilizing Portable Learning Technologies to Improve Student Engagement and Retention," IEEE Trans. Educ., vol. 63, no. 1, pp. 3238, Feb. 2020, doi: 10.1109/TE.2019.2941700.

[7] D. W. Knight, L. E. Carlson, and J. F. Sullivan. "Improving Engineering Student Retention through Hands-On, Team Based, First-Year Design Projects," $31^{\text {st }}$ International Conference on Research in Engineering Education, Honolulu, HI, Jun. 2007, pp. 1-13, https://pdfs.semanticscholar.org/b12d/292eb81507aee8e343f59cc87b3037951bfb.pdf.

[8] J. Linsey, B. Cobb, D. Jensen, K. Wood, and S. Eways. "Methodology And Tools For Developing Hands On Active Learning Activities," ASEE Annual Conference \& Exposition, Chicago, Illinois, Jun. 2006, pp. 11.927.1-11.927.31, file://C:/Users/swarren/Downloads/methodology-and-tools-for-developing-hands-onactive-learning-activities.pdf.

[9] K. J. Reid and D. M. Ferguson. "Do design experiences in engineering build a 'growth mindset' in students?," IEEE Integrated STEM Education Conference, Princeton, NJ, Mar. 2014, doi: 10.1109/ISECon.2014.6891046.

[10] J. J. Pembridge and K. J. Rodgers. "Examining Self-Efficacy and Growth Mindset in an Introductory Computing Course," IEEE Frontiers in Education Conference (FIE), San Jose, CA, Oct. 2018, doi: 10.1109/FIE.2018.8658728.

[11] S. Fantini, C. Bennis, and D. Kaplan. "Biomedical Engineering Continues to Make the Future," IEEE Pulse, vol. 2, no. 4, pp. 70-73, Jul. 2011, doi: 10.1109/MPUL.2011.941720.

[12] Aspiring Docs. "What You Need to Know About the MCAT® Exam," 2020, https://students-residents.aamc.org/choosing-medical-career/article/preparing-mcat-exam/.

[13] “ABET | ABET Accreditation,” ABET $\mid$ ABET Accreditation, 2020, https://www.abet.org/.

[14] J. D. Gassert and J. D. Enderle. "Design versus research in BME accreditation [ABET requirements and why research cannot substitute for design]," IEEE Engineering in Medicine and Biology Magazine, vol. 27, no. 2, pp. 80-85, Apr. 2008.

[15] "BME Design Course Syllabus and Outline," Jan. 14, 2020, https://bmedesign.engr.wisc.edu/course/syllabus/.

[16] G. N. Svarovsky and D. W. Shaffer. "Design meetings and design notebooks as tools for reflection in the engineering design course," Frontiers in Education. $36^{\text {th }}$ Annual Conference, San Diego, CA, Oct. 2006, pp. M2G-7-M2G-12, doi: 10.1109/FIE.2006.322548.

[17] "Google," 2020, https://www.google.com/.

[18] "Google Scholar," 2020, https://scholar.google.com/.

[19] IEEE. "IEEE Xplore Digital Library," 2020, https://ieeexplore.ieee.org/Xplore/home.jsp.

[20] “ASEE PEER Document Repository," 2020, https://peer.asee.org/.

[21] "Journal of Engineering Education - Wiley Online Library," 2020, https://onlinelibrary.wiley.com/journal/21689830. 
[22] ASEE. "Computers in Education Journal: American Society for Engineering Education," https://www.asee.org/papers-and-publications/publications/divisionpublications/computers-in-education-journal.

[23] ASEE. "American Society for Engineering Education," https://www.asee.org/.

[24] "IEEE Engineering in Medicine and Biology Society," 2020.

[25] "Zotero | Your personal research assistant," 2020, https://www.zotero.org/.

[26] K. Billiar and K. A. Marengo. "Canine hip forces: The ups and downs of project-based learning of static equilibrium," ASEE Annual Conference \& Exposition, Columbus, $\mathrm{OH}$, Jun. 2017, https://peer.asee.org/canine-hip-forces-the-ups-and-downs-of-project-basedlearning-of-static-equilibrium.

[27] E. G. Meyer and B. L. Ulrey. "Sensing Angular Kinematics by Embedding an Opensource Electronics Design Project into a Required Biomechanics Course," ASEE Annual Conference \& Exposition, New Orleans, LA, Jun. 2016, https://peer.asee.org/sensingangular-kinematics-by-embedding-an-open-source-electronics-design-project-into-arequired-biomechanics-course.

[28] R. Goldberg. "The 'Invisible Handshake' Project as a Practical, Hands-on Experience in a Biomedical Electronics Class," ASEE Annual Conference \& Exposition, New Orleans, LA, Jun. 2016, https://peer.asee.org/the-invisible-handshake-project-as-a-practical-handson-experience-in-a-biomedical-electronics-class.

[29] M. Nasir, J. Seta, and E. G. Meyer. "Introducing High School Students to Biomedical Engineering through Summer Camps," ASEE Annual Conference \& Exposition, Indianapolis, IN, Jun. 2014, pp. 24.809.1-24.809.15, https://peer.asee.org/introducinghigh-school-students-to-biomedical-engineering-through-summer-camps.

[30] C. Zapanta et al. "An Integrated Undergraduate Biomedical Engineering Laboratory Course," ASEE Annual Conference \& Exposition, Austin, TX, Jun. 2009, pp. 14.200.114.200.32, https://peer.asee.org/an-integrated-undergraduate-biomedical-engineeringlaboratory-course.

[31] P. Rousche et al. "A Bioengineering Summer Day Camp For High School Science Students And Teachers," ASEE Annual Conference \& Exposition, Chicago, IL, Jun. 2006, pp. 11.6.1-11.6.12, https://peer.asee.org/a-bioengineering-summer-day-camp-for-highschool-science-students-and-teachers.

[32] J. L. Cezeaux, M. J. Rust, R. Gettens, R. D. Beach, and J. A. Criscuolo. "Implementation of a Biomedical Engineering Summer Program for High School Students," ASEE Annual Conference \& Exposition, Vancouver, BC, Jun. 2011, pp. 22.807.1-22.807.17, https://peer.asee.org/implementation-of-a-biomedical-engineering-summer-program-forhigh-school-students.

[33] Y.-C. Kuo, C.-Y. Kuo, and C.-H. Kuo. "Designing a reconfigurable biopotential amplifiers for medical instrumentation course," IEEE International Conference on Systems, Man, and Cybernetics (SMC), San Diego, CA, Oct. 2014, pp. 1186-1191, doi: 10.1109/SMC.2014.6974075.

[34] J. D. DesJardins, E. Breazel, M. Reba, I. Viktorova, J. B. Matheny, and T. R. Khan. "Emphasizing Core Calculus Concepts Using Biomedical Applications to Engage, Mentor, and Retain STEM Students," ASEE Annual Conference \& Exposition, Jun. 2012, pp. 25.521.1-25.521.14, https://peer.asee.org/emphasizing-core-calculus-concepts-usingbiomedical-applications-to-engage-mentor-and-retain-stem-students. 
[35] B. Sun, C. Xiong, W. Chen, Q. Zhang, L. Mao, and Q. Zhang. "A novel design method of anthropomorphic prosthetic hands for reproducing human hand grasping," $36^{\text {th }}$ Annual International Conference of the IEEE Engineering in Medicine and Biology Society, Chicago, IL, Aug. 2014, pp. 6215-6221, doi: 10.1109/EMBC.2014.6945049.

[36] R. Goldberg, R. Dennis, and C. Finley. "Integrating Hands On Design Experiences Into The Curriculum," ASEE Annual Conference \& Exposition, Louisville, KY, Jun. 2010, pp. 15.765.1-15.765.13, https://peer.asee.org/integrating-hands-on-design-experiences-intothe-curriculum.

[37] P. Mellodge and B. Deschenes. "Digital Health: A Sophomore Level Interdisciplinary Engineering Design Project Course," ASEE Annual Conference \& Exposition, Austin, TX, Jun. 2009, pp. 14.490.1-14.490.13, https://peer.asee.org/digital-health-a-sophomore-levelinterdisciplinary-engineering-design-project-course.

[38] J. Tranquillo and D. Cavanagh. "A Project Driven Approach To Biomedical Signals And Systems," ASEE Annual Conference \& Exposition, Honolulu, HI, Jun. 2007, pp. 12.101.112.101.12, https://peer.asee.org/a-project-driven-approach-to-biomedical-signals-andsystems.

[39] R. R. Harrison et al. "Wireless Neural/EMG Telemetry Systems for Small Freely Moving Animals," IEEE Trans. Biomed. Circuits Syst., vol. 5, no. 2, pp. 103-111, Apr. 2011, doi: 10.1109/TBCAS.2011.2131140.

[40] E. Haase. "Modeling and Design: a Hands-on Introduction to Biomedical Engineering," ASEE Annual Conference \& Exposition, Salt Lake City, UT, Jun. 2018, https://peer.asee.org/modeling-and-design-a-hands-on-introduction-to-biomedicalengineering.

[41] J. Yao and S. Warren. "Stimulating Student Learning With A Novel 'In House' Pulse Oximeter Design," ASEE Annual Conference \& Exposition, Portland, OR, Jun. 2005, pp. 10.1138.1-10.1138.14, https://peer.asee.org/stimulating-student-learning-with-a-novel-inhouse-pulse-oximeter-design.

[42] G. Baura, V. Chen, and L. Kallemeyn. "Building a Functional Cardiograph Over Four Semesters: Part 2 - Programming a Microcontroller," ASEE Annual Conference \& Exposition, Tampa, FL, Jun. 2019, https://peer.asee.org/building-a-functionalcardiograph-over-four-semesters-part-2-programming-a-microcontroller.

[43] G. Baura, L. Kallemeyn, N. Arroyo, V. C. F. Chen, and A. Beale. "Work in Progress: Building a Functional Cardiograph Over Four Semesters," ASEE Annual Conference \& Exposition, Salt Lake City, UT, Jun. 2018, https://peer.asee.org/work-in-progressbuilding-a-functional-cardiograph-over-four-semesters.

[44] P. Bhatti, J. Falcone, and J. McClellan. "The Coding Of Sound By A Cochlear Prosthesis: An Introductory Signal Processing Lab," ASEE Annual Conference \& Exposition, Louisville, KY, Jun. 2010, pp. 15.1214.1-15.1214.8, https://peer.asee.org/the-coding-ofsound-by-a-cochlear-prosthesis-an-introductory-signal-processing-lab.

[45] X. Qian et al. "Brain-Region-Specific Organoids Using Mini-bioreactors for Modeling ZIKV Exposure," NCBI, vol. 165, no. 5, pp. 1238-1254, May 2016, doi: 10.1016/j.cell.2016.04.032.

[46] S. Farrell, J. Vernengo, T. Merrill, J. Kadlowec, M. M. Staehle, and R. Polikar. "Organizing the Engineering Curriculum with Biomedically Related Learning Modules," ASEE Annual Conference \& Exposition, Indianapolis, IN, Jun. 2014, pp. 24.963.1-24.963.11, 
https://peer.asee.org/organ-izing-the-engineering-curriculum-with-biomedically-relatedlearning-modules.

[47] P. King. "Freshman Biomedical Engineering Design Projects: What Can Be Done?," ASEE Annual Conference \& Exposition, Jun. 2002, pp. 7.576.1-7.576.7, https://peer.asee.org/freshman-biomedical-engineering-design-projects-what-can-be-done.

[48] J. Bazil, et al. "Bioinstrumentation Instruction Through Hybrid Wet/Circuit Laboratory Activities," ASEE Annual Conference \& Exposition, Chicago, IL, Jun. 18-21, 2006,https://scholar.google.com/scholar?lookup=0\&q=allintitle:+Bioinstrumentation\%0A instruction+through+hybrid+wet/circuit+laboratory+activities\&hl=en\&as_sdt=0,31.

[49] P. Bedenbaugh. "A Team Based Nerve Cuff Simulation Project In A Third Year Foundations Of Biomedical Engineering Course," ASEE Annual Conference \& Exposition, Louisville, KY, Jun. 2010, pp. 15.105.1-15.105.26, https://peer.asee.org/ateam-based-nerve-cuff-simulation-project-in-a-third-year-foundations-of-biomedicalengineering-course.

[50] A. M. Kyle, D. C. Jangraw, M. B. Bouchard, and M. E. Downs. "Bioinstrumentation: A Project-Based Engineering Course," IEEE Trans. Educ., vol. 59, no. 1, pp. 52-58, Feb. 2016, doi: 10.1109/TE.2015.2445313.

[51] A. Atasoy et al. "Biomechanical Design of an Anthropomorphic Prosthetic Hand," $7^{\text {th }}$ IEEE International Conference on Biomedical Robotics and Biomechatronics (Biorob), Enschede, Netherlands, Aug. 2018, pp. 732-736, doi: 10.1109/BIOROB.2018.8487680.

[52] R. Jones, M. Tham, and A. Barnes. "Development of an Undergraduate Control Engineering Design Project: PID Control of Blood Glucose Levels in Type 1 Diabetes Mellitus Subjects," $9^{\text {th }}$ International Conference on Information Technology in Medicine and Education (ITME), Hangzhou, China, Oct. 2018, pp. 142-147, doi: 10.1109/ITME.2018.00041.

[53] C. Supakitamonphan, S. Suksri, N. Pramunrueang, and T. Chaichana. "Electric prosthetic hand activated using two-channel surface electromyography," 8 th Biomedical Engineering International Conference (BMEiCON), Pattaya, Thailand, Nov. 2015, pp. 1-4, doi: 10.1109/BMEiCON.2015.7399519.

[54] M. Opuszynski, R. Andrews, J. Potvin, T. BouRamia, and Sun, Ying. "Experiential learning in an undergraduate biomeasurement course: Heart-rate meter," IEEE $35^{\text {th }}$ Annual Northeast Bioengineering Conference, Boston, MA, Apr. 2009, pp. 1-2, doi: 10.1109/NEBC.2009.4967643.

[55] M. Tamayo, A. Westover, and Y. Sun. "Microcontroller based pulse oximeter for undergraduate capstone design," IEEE $36^{\text {th }}$ Annual Northeast Bioengineering Conference (NEBEC), New York, NY, Mar. 2010, pp. 1-2, doi: 10.1109/NEBC.2010.5458198.

[56] F. Breau, S. Maio-Cannon, R. Davis, J. Wu, J. DiCecco, and Y. Sun. "The Neuron Emulator: an undergraduate Biomedical Engineering design project," IEEE $31^{\text {st }}$ Annual Northeast Bioengineering Conference, 2005., Hoboken, NJ, Apr. 2005, pp. 28-29, doi: 10.1109/NEBC.2005.1431910.

[57] D. S. Long and T. G. McKay. "A design project based approach to teaching undergraduate instrumentation," IEEE International Conference on Teaching, Assessment and Learning for Engineering (TALE), Wellington, New Zealand, Dec. 2014, pp. 41-44, doi: 10.1109/TALE.2014.7062557.

[58] N. Constant, T. Wang, and K. Mankodiya. "Pulseband: A hands-on tutorial on how to design a smart wristband to monitor heart-rate," IEEE Virtual Conference on Applications 
of Commercial Sensors (VCACS), Raleigh, NC, Mar. 2015, pp. 1-3, doi: 10.1109/VCACS.2015.7439565.

[59] J. E. Bohorquez and R. B. Montero. "Board 1: Introduction to Design Thinking and Human Centered Design in the Biomedical Engineering Freshman Year," ASEE Annual Conference \& Exposition, Tampa, FL, Jun. 2019, https://peer.asee.org/board-1introduction-to-design-thinking-and-human-centered-design-in-the-biomedicalengineering-freshman-year.

[60] A. Lai, E. Soohoo, D. L. Nelson, and C. M. Zapanta. "Board 7: Work in Progress: Approaches to Introduce Biomedical Engineering Design to a Class with Diverse STEM Backgrounds," ASEE Annual Conference \& Exposition, Tampa. FL, Jun. 2019, https://peer.asee.org/board-7-work-in-progress-approaches-to-introduce-biomedicalengineering-design-to-a-class-with-diverse-stem-backgrounds.

[61] M. B. Silver-Thorn. "A rehabilitation engineering course for biomedical engineers," IEEE Trans. Educ., vol. 45, no. 4, pp. 299-306, Nov. 2002, doi: 10.1109/TE.2002.803402.

[62] B. Zeng, M. Huang, F. Chen, and L. Chen, "Exploration on Undergraduate Curriculum Reform of Hospital-Oriented Biomedical Engineering Major," $2^{\text {nd }}$ International Conference on Biomedical Engineering and Informatics, Tianjin, China, Oct. 2009, pp. 13, doi: 10.1109/BMEI.2009.5304919.

[63] L. S. Nagurney. "The evolution of a bioinstrumentation course," $37^{\text {th }}$ Annual Frontiers In Education Conference - Global Engineering: Knowledge Without Borders, Opportunities Without Passports, Milwaukee, WI, Oct. 2007, pp. F1C-5-F1C-8, doi: 10.1109/FIE.2007.4417960.

[64] A. C. H. Yu, B. Y. S. Yiu, I. K. H. Tsang, and P. Y. S. Cheung. "Towards integrative learning in biomedical engineering: A project course on electrocardiogram monitor design - IEEE Conference Publication," IEEE, 2009, doi: 5350523.

[65] A. D. C. Chan and S. Nizami. "Integrative learning through the design of an electrocardiogram acquisition system," Annual International Conference of the IEEE Engineering in Medicine and Biology Society, Aug. 2011, pp. 3624-3627, doi: 10.1109/IEMBS.2011.6090608.

[66] R. Aldridge, T. Brandt, and C. Parikh. "Autonomous robot design and build: novel handson experience for undergraduate students," Trans. Tech. STEM Educ., vol. 2, pp. 3-10, Mar. 2017.

[67] R. R. Fletcher, N. M. Oreskovic, and A. I. Robinson. "Design and clinical feasibility of personal wearable monitor for measurement of activity and environmental exposure," $36^{\text {th }}$ Annual International Conference of the IEEE Engineering in Medicine and Biology Society, Chicago, IL, Aug. 2014, pp. 874-877, doi: 10.1109/EMBC.2014.6943730.

[68] H. Jeong et al. "NFC-enabled, tattoo-like stretchable biosensor manufactured by 'cut-andpaste' method," $39^{\text {th }}$ Annual International Conference of the IEEE Engineering in Medicine and Biology Society (EMBC), Seogwipo, South Korea, Jul. 2017, pp. 40944097, doi: 10.1109/EMBC.2017.8037756.

[69] C. Xiong, W. Chen, B. Sun, M. Liu, S. Yue, and W. Chen. "Design and Implementation of an Anthropomorphic Hand for Replicating Human Grasping Functions," IEEE Trans. Robot., vol. 32, no. 3, pp. 652-671, Jun. 2016, doi: 10.1109/TRO.2016.2558193.

[70] R. T. Castles. "Flipping the Microprocessors Classroom: A Comparative Assessment," ASEE Annual Conference \& Exposition, New Orleans, LA, Jun. 2016, https://peer.asee.org/flipping-the-microprocessors-classroom-a-comparative-assessment. 
[71] P. J. Hill, B. L. Kirkland, Y. Koshka, R. W. Sullivan, and T. W. Stone. "A Multidisciplinary Undergraduate Nanotechnology Education Program with Integrated Laboratory Experience and Outreach Activities," ASEE Annual Conference \& Exposition, New Orleans, LA, Jun. 2016, https://peer.asee.org/a-multidisciplinary-undergraduatenanotechnology-education-program-with-integrated-laboratory-experience-and-outreachactivities.

[72] S. Farrell, T. M. Bayles, and P. M. Kieran. "An Adaptable and Transferrable Project Based on a Heart-lung Machine Design Challenge," ASEE Annual Conference \& Exposition, New Orleans, LA, Jun. 2016, https://peer.asee.org/an-adaptable-andtransferrable-project-based-on-a-heart-lung-machine-design-challenge.

[73] F. Yildiz, H. C. Collins, J. L. Leatherwood, M. M. Beverly, and M. J. Anderson. "Design and Development of a Non-Contact Thermography Device for Equine Research," ASEE Annual Conference \& Exposition, New Orleans, LA, Jun. 2016, https://peer.asee.org/design-and-development-of-a-non-contact-thermography-device-forequine-research.

[74] B. P. Ruddy and P. F. Nielsen. "Work in Progress: The Consumer Breathalyzer as a Model Design Project in Introductory Instrumentation," ASEE Annual Conference \& Exposition, New Orleans, LA, Jun. 2016, https://peer.asee.org/work-in-progress-theconsumer-breathalyzer-as-a-model-design-project-in-introductory-instrumentation.

[75] J. H. Choi. "Work in Progress: The Incorporation of Hands-On, Team-Based Design Challenges in a Large Enrollment Introductory Biomedical Engineering Course," ASEE Annual Conference \& Exposition, New Orleans, LA, Jun. 2016, https://peer.asee.org/work-in-progress-the-incorporation-of-hands-on-team-based-designchallenges-in-a-large-enrollment-introductory-biomedical-engineering-course.

[76] W. Joo. "Work in Progress: Hands-On Practice of Implant Surgery Using Artificial Bone in Design Course," ASEE Annual Conference \& Exposition, New Orleans, LA, Jun. 2016, https://peer.asee.org/work-in-progress-hands-on-practice-of-implant-surgery-usingartificial-bone-in-design-course.

[77] R. Schmedlen, S. M. Kusano, J. Gosbee, J. C. Lee, and J. P. Stegemann, "The Medical Device Sandbox: A Creative Learning Experience for BME Students and Medical Learners," ASEE Annual Conference \& Exposition, New Orleans, LA, Jun. 2016, https://peer.asee.org/the-medical-device-sandbox-a-creative-learning-experience-for-bmestudents-and-medical-learners.

[78] D. Gibson and P. Brackin, "Capstone Design Projects: Helping the Disabled," ASEE Annual Conference \& Exposition, Montreal, Canada, 2002, https://peer.asee.org/capstonedesign-projects-helping-the-disabled.

[79] E. Bernitt, C. Oettmeier, D. Henrichs, and H.-G. Dobereiner. "A Low-Cost Bio-Imaging and Incubation System | Proceedings of the 9th EAI International Conference on Bioinspired Information and Communications Technologies (formerly BIONETICS)," BICT'15: Proceedings of the 9th EAI International Conference on Bio-inspired Information and Communications Technologies, 2016, https://dl.acm.org/doi/abs/10.4108/eai.3-12-2015.2262490.

[80] Z. Grier et al. "A low-cost do-it-yourself microscope kit for hands-on science education," Optics Education and Outreach V, Sep. 2018, vol. 10741, p. 107410K, doi: 10.1117/12.2320655. 
[81] A. B. Jani, R. Bagree, and A. K. Roy. "Design of a low-power, low-cost ECG EMG sensor for wearable biometric and medical application," IEEE Sensors, Oct. 2017, pp. 13, doi: 10.1109/ICSENS.2017.8234427.

[82] M. A. F. Pimentel et al. "A \$5 smart blood pressure system," Appropriate Healthcare Technologies for Low Resource Settings (AHT 2014), Sep. 2014, pp. 1-4, doi: 10.1049/cp.2014.0784.

[83] J. Casey, A. Mantzavinou, B. J. Ranger, R. G. Secundo, and R. L. Sheridan. "A costefficient spring-powered dermatome to treat skin trauma," IEEE Healthcare Innovation Conference (HIC), Seattle, WA, Oct. 2014, pp. 227-230, doi:

10.1109/HIC.2014.7038916.

[84] K. Cruden et al. "Frugal Skin Graft Expansion Device," 2018 IEEE Global Humanitarian Technology Conference (GHTC), Oct. 2018, pp. 1-6, doi: 10.1109/GHTC.2018.8601640.

[85] M. J. Wolf, R. Staudt, A. Gambier, W. Storhas, and E. Badreddin. "On setting-up a portable low-cost real-time control system for research and teaching with application to bioprocess $\mathrm{pH}$ control," IEEE Control Applications, (CCA) Intelligent Control, (ISIC), Jul. 2009, pp. 1631-1636, doi: 10.1109/CCA.2009.5280948.

[86] M. J. Fuller, K. Ranganathan, Shiwei Zhou, T. N. Blalock, J. A. Hossack, and W. F. Walker, "Portable, low-cost medical ultrasound device prototype," IEEE Ultrasonics Symposium, Aug. 2004, vol. 1, pp. 106-109 Vol.1, doi: 10.1109/ULTSYM.2004.1417679.

[87] K. C. Kim et al. "Smartphone-based portable ultrasound imaging system: A primary result," IEEE International Ultrasonics Symposium (IUS), Jul. 2013, pp. 2061-2063, doi: 10.1109/ULTSYM.2013.0526.

[88] T.- Pan, Ping-Lin Fan, H. K. Chiang, Rong-Seng Chang, and J.- Jiang. "Mechatronic experiments course design: a myoelectric controlled partial-hand prosthesis project," IEEE Trans. Educ., vol. 47, no. 3, pp. 348-355, Aug. 2004, doi: 10.1109/TE.2004.825528.

[89] S. Warren et al. "Design projects motivated and informed by the needs of severely disabled autistic children," $38^{\text {th }}$ Annual International Conference of the IEEE Engineering in Medicine and Biology Society (EMBC), Orlando, FL, Aug. 2016, pp. 3015-3018, doi: 10.1109/EMBC.2016.7591364.

[90] V.-L. Gale, V. Bill, and J. Si. "Work in Progress: Multidisciplinary, Vertically Integrated Projects Course on 3-D Printed Biomedical Devices," ASEE Annual Conference \& Exposition, Tampa, FL, Jun. 2019, https://peer.asee.org/work-in-progressmultidisciplinary-vertically-integrated-projects-course-on-3-d-printed-biomedical-devices.

[91] C. Carlson, D. X. Ren, and S. Warren. "An Improved Cellphone-based Wearable Electrocardiograph Project for a Biomedical Instrumentation Course Sequence," $A S E E$ Annual Conference \& Exposition, Tampa, FL, Jun. 2019, https://peer.asee.org/animproved-cellphone-based-wearable-electrocardiograph-project-for-a-biomedicalinstrumentation-course-sequence.

[92] R. W. Carlsen, S. Zyhier, and A. Sirinterlikci. "Project-based Learning: Engaging Biomedical Engineering Sophomores Through a Collaborative Vein-finder Device Project with Nursing," ASEE Annual Conference \& Exposition, Salt Lake City, UT, Jun. 2018, https://peer.asee.org/project-based-learning-engaging-biomedical-engineeringsophomores-through-a-collaborative-vein-finder-device-project-with-nursing.

[93] M. J. Rust and A. W. Browne. "Engaging Undergraduate Biomedical Engineering Students in Lab on a Chip Research through a Course-Based Project," ASEE Annual Conference \& Exposition, Atlanta, Georgia, Jun. 2013, pp. 23.493.1-23.493.10, 
https://peer.asee.org/engaging-undergraduate-biomedical-engineering-students-in-lab-ona-chip-research-through-a-course-based-project.

[94] S. Warren. "Student Proposals for Design Projects to Aid Children with Severe Disabilities," ASEE Annual Conference \& Exposition, New Orleans, LA, Jun. 2016, https://peer.asee.org/student-proposals-for-design-projects-to-aid-children-with-severedisabilities.

[95] S. Warren, C. Carlson, A. McKittrick, and S. Wang. "Board 79: A Wearable Electrocardiograph as a Means to Combine Measurement and Makerspace Concepts in a Biomedical Instrumentation Course Sequence," ASEE Annual Conference \& Exposition, Salt Lake City, UT, Jun. 2018, https://peer.asee.org/board-79-a-wearableelectrocardiograph-as-a-means-to-combine-measurement-and-makerspace-concepts-in-abiomedical-instrumentation-course-sequence.

[96] T. E. Allen and D. Chen. "Patient Centered Design in Undergraduate Biomedical Engineering," ASEE Annual Conference \& Exposition, Salt Lake City, UT, Jun. 2018, https://peer.asee.org/patient-centered-design-in-undergraduate-biomedical-engineering.

[97] J. L. Cezeaux, E. Haffner, A. Kaboray, and C. Hasenjager. "Design For The Disabled As An Interdisciplinary Laboratory Project," 2007, https:/www.semanticscholar.org/paper/Design-For-The-Disabled-As-AnInterdisciplinary-Cezeaux-Haffner/663a07fb89ab57bbe5b69f1e912ab01832c3cb64.

[98] R. L. Nagel, O. Pierrakos, J. K. Nagel, and E. C. Pappas. "On a Client-Centered, Sophomore Design Course Sequence," ASEE Annual Conference \& Exposition, San Antonio, TX, Jun. 2012, pp. 25.990.1-25.990.15, https://peer.asee.org/on-a-clientcentered-sophomore-design-course-sequence.

[99] M. R. Caplan, C. M. DuBois, S. Brenna, N. A. Shulman, and J. Coursen. "Curiosity and Connections (Entrepreneurial Mindset) in BME Sophomore Design," Pacific Southwest Section Meeting, Tempe, AR, Apr. 2017, https://peer.asee.org/curiosity-and-connectionsentrepreneurial-mindset-in-bme-sophomore-design.

[100] M. R. Caplan and J. Coursen. "Sophomore Design Course on Virtual Prototyping," ASEE Annual Conference \& Exposition, Columbus, OH, Jun. 2017, https://peer.asee.org/sophomore-design-course-on-virtual-prototyping.

[101] K. Reid, S. M. Montenery, and C. M. Hetrick. "An Innovative Interdisciplinary Student Project: Engineering and Nursing," ASEE Annual Conference \& Exposition, Vancouver, BC, Jun. 2011, pp. 22.179.1-22.179.12, https://peer.asee.org/an-innovativeinterdisciplinary-student-project-engineering-and-nursing.

[102] G. W. Bucks, et al. "Engineering Your Community: Experiences of Students in a ServiceLearning Engineering Design Course," ASEE Annual Conference \& Exposition, Seattle, WA, Jun. 2015, pp. 26.649.1-26.649.12, https://peer.asee.org/engineering-yourcommunity-experiences-of-students-in-a-service-learning-engineering-design-course.

[103] S. Lai-Yuen and M. Herrera. "Integrating Real World Medical Device Projects Into Manufacturing Education," ASEE Annual Conference \& Exposition, Austin, TX, Jun. 2009, pp. 14.767.1-14.767.10, https://peer.asee.org/integrating-real-world-medical-deviceprojects-into-manufacturing-education.

[104] D. P. Cavanagh and J. Tranquillo. "Diseases, Devices, and Patients: Exposing BME Students to the Patient Experience," ASEE Annual Conference \& Exposition, Columbus, $\mathrm{OH}$, Jun. 2017, https://peer.asee.org/diseases-devices-and-patients-exposing-bmestudents-to-the-patient-experience. 
[105] R. A. Lasher, J. C. Wolchok, M. K. Parikh, J. P. Kennedy, and R. W. Hitchcock. "Design and characterization of a modified T-flask bioreactor for continuous monitoring of engineered tissue stiffness," Biotechnol. Prog., vol. 26, no. 3, pp. 857-864, 2010, doi: 10.1002/btpr.380.

[106] D. K. Rajan et al. "A Portable Live-Cell Imaging System With an Invert-UprightConvertible Architecture and a Mini-Bioreactor for Long-Term Simultaneous Cell Imaging, Chemical Sensing, and Electrophysiological Recording," IEEE Access, vol. 6, pp. 11063-11075, 2018, doi: 10.1109/ACCESS.2018.2804378.

[107] N. Bhattarai et al. "Enhancing Undergraduate Students' Learning and Research Experiences through Hands-on Experiments in Bio-nanoengineering," ASEE Annual Conference \& Exposition, Seattle, WA, Jun. 2015, pp. 26.673.1-26.673.15, https://peer.asee.org/enhancing-undergraduate-students-learning-and-researchexperiences-through-hands-on-experiments-in-bio-nanoengineering.

[108] A. J. Nimunkar, J. P. Puccinelli, M. S. Bollom, and W. J. Tompkins. "Using Guided Design Instruction to Motivate BME Sophomore Students to Learn Multidisciplinary Engineering Skills," ASEE Annual Conference \& Exposition, Indianapolis, IN, Jun. 2014, pp. 24.1331.1-24.1331.17, https://peer.asee.org/using-guided-design-instruction-tomotivate-bme-sophomore-students-to-learn-multidisciplinary-engineering-skills.

[109] N. Comolli, W. Kelly, and Q. Wu. "The Artificial Kidney: Investigating Current Dialysis Methods As A Freshman Design Project," ASEE Annual Conference \& Exposition, Louisville, KY, Jun. 2010, pp. 15.1205.1-15.1205.15, https://peer.asee.org/the-artificialkidney-investigating-current-dialysis-methods-as-a-freshman-design-project.

[110] M. Henkel et al. "Teaching bioprocess engineering to undergraduates: Multidisciplinary hands-on training in a one-week practical course," Biochem. Mol. Biol. Educ., vol. 43, no. 3, pp. 189-202, 2015, doi: 10.1002/bmb.20860.

[111] J. Vernengo, C. Purdy, and S. Farrell, "Undergraduate Laboratory Experiment Teaching Fundamental Concepts of Rheology In Context of Sickle Cell Anemia," Rowan Univ., 2014, https://eric.ed.gov/?id=EJ1038691.

[112] A. Saterbak. "Laboratory Courses Focused On Tissue Engineering Applications," ASEE Annual Conference \& Exposition, Montreal, Canada, Jun. 2002, pp. 7.786.1-7.786.13, https://peer.asee.org/laboratory-courses-focused-on-tissue-engineering-applications.

[113] A. Saterbak, K. San, and L. McIntire. "Development Of A Novel Foundation Course For Biomedical Engineering Curriculum," ASEE Annual Conference \& Exposition, Albuquerque, NM, Jun. 2001, pp. 6.372.1-6.372.6, https://peer.asee.org/development-of-anovel-foundation-course-for-biomedical-engineering-curriculum.

[114] R. Childers and S. Wilhelm. "A Gold Nanoparticle-based Lab Experiment Sequence to Enhance Learning in Biomedical Nanotechnology at the Undergraduate Level," ASEE Annual Conference \& Exposition, Tampa, FL, Jun. 2019, https://peer.asee.org/a-goldnanoparticle-based-lab-experiment-sequence-to-enhance-learning-in-biomedicalnanotechnology-at-the-undergraduate-level. 


\section{Appendix A - Literature Survey Results}

For the "Course Level," $\mathrm{F}=$ Freshman, So $=$ Sophomore, $\mathrm{J}=$ Junior, and $\mathrm{S}=$ Senior.

For the "Emphasis Area," B = Biomechanics, $\mathrm{C}=$ Computation, $\mathrm{SD}=$ Sensors \& Devices, and $\mathrm{T}=$ Tissue Engineering.

\begin{tabular}{|c|c|c|c|c|c|c|c|}
\hline First Author & Year & Title & Affiliated Institution & $\begin{array}{l}\text { Course } \\
\text { Level }\end{array}$ & $\begin{array}{l}\text { Technical } \\
\text { Area }\end{array}$ & $\begin{array}{l}\text { Emphasis } \\
\text { Area }\end{array}$ & Assessment Method(s) \\
\hline Billiar [26] & 2017 & $\begin{array}{l}\text { Canine hip forces: The ups and downs of } \\
\text { project-based learning of static equilibrium }\end{array}$ & $\begin{array}{l}\text { Worcester Polytechnic } \\
\text { Institute }\end{array}$ & So & $\begin{array}{l}\text { Acetabular Cup } \\
\text { for Canine Hip }\end{array}$ & B & $\begin{array}{l}\text { Formative Assignment; } \\
\text { Report with Rubric; Self- } \\
\text { Assessment; Quizzes }\end{array}$ \\
\hline Meyer [27] & 2016 & $\begin{array}{l}\text { Sensing Angular Kinematics by Embedding } \\
\text { an Open-source Electronics Design Project } \\
\text { into a Required Biomechanics Course }\end{array}$ & $\begin{array}{l}\text { Lawrence Technological } \\
\text { University }\end{array}$ & $\mathrm{J} / \mathrm{S}$ & $\begin{array}{l}\text { Angular } \\
\text { Velocity } \\
\text { Measurement } \\
\text { Sensor }\end{array}$ & $\mathrm{B}, \mathrm{C}$ & $\begin{array}{l}\text { Report; Presentation; } \\
\text { Pre/Post Surveys }\end{array}$ \\
\hline Goldberg [28] & 2016 & $\begin{array}{l}\text { The 'Invisible Handshake' Project as a } \\
\text { Practical, Hands-on Experience in a } \\
\text { Biomedical Electronics Class }\end{array}$ & $\begin{array}{l}\text { University of North } \\
\text { Carolina }\end{array}$ & $\mathrm{So} / \mathrm{J}$ & Various & $\mathrm{B}, \mathrm{C}, \mathrm{SD}$ & $\begin{array}{l}\text { Pre/Post Surveys; Final } \\
\text { Project }\end{array}$ \\
\hline Nasir [29] & 2014 & $\begin{array}{l}\text { Introducing High School Students to } \\
\text { Biomedical Engineering through Summer } \\
\text { Camps }\end{array}$ & $\begin{array}{l}\text { Lawrence Technological } \\
\text { University }\end{array}$ & HS & Various & $\begin{array}{l}\mathrm{B}, \mathrm{C}, \mathrm{SD}, \\
\mathrm{T}\end{array}$ & $\begin{array}{l}\text { Pre/Post Surveys; Student } \\
\text { Feedback }\end{array}$ \\
\hline Zapanta [30] & 2009 & $\begin{array}{l}\text { An Integrated Undergraduate Biomedical } \\
\text { Engineering Laboratory Course }\end{array}$ & $\begin{array}{l}\text { Carnegie Mellon } \\
\text { University }\end{array}$ & So & Various & $\mathrm{B}, \mathrm{C}, \mathrm{T}$ & $\begin{array}{l}\text { Lab Notebook with } \\
\text { Rubric; Survey }\end{array}$ \\
\hline Rousche [31] & 2006 & $\begin{array}{l}\text { A Bioengineering Summer Day Camp For } \\
\text { High School Science Students And Teachers }\end{array}$ & $\begin{array}{l}\text { University of Illinois- } \\
\text { Chicago }\end{array}$ & HS & Various & $\mathrm{B}, \mathrm{SD}, \mathrm{T}$ & Pre/Post Surveys \\
\hline Cezeaux [32] & 2011 & $\begin{array}{l}\text { Implementation of a Biomedical Engineering } \\
\text { Summer Program for High School Students }\end{array}$ & $\begin{array}{l}\text { Western New England } \\
\text { College }\end{array}$ & HS & Various & $\mathrm{B}, \mathrm{SD}, \mathrm{T}$ & Pre/Post Surveys \\
\hline Kuo [33] & 2014 & $\begin{array}{l}\text { Designing a reconfigurable biopotential } \\
\text { amplifiers for medical instrumentation course }\end{array}$ & $\begin{array}{l}\text { National Taiwan } \\
\text { University of Science } \\
\text { and Technology }\end{array}$ & $\mathrm{S}$ & $\begin{array}{l}\text { Biopotential } \\
\text { Amplifier }\end{array}$ & $\mathrm{C}$ & Survey \\
\hline DesJardins [34] & 2012 & $\begin{array}{l}\text { Emphasizing Core Calculus Concepts Using } \\
\text { Biomedical Applications to Engage, Mentor, } \\
\text { and Retain STEM Students }\end{array}$ & Clemson University & F/So & Orthopaedics & $\mathrm{C}$ & $\begin{array}{l}\text { Pre/Post Surveys; Exams; } \\
\text { Exit Interviews }\end{array}$ \\
\hline Sun [35] & 2014 & $\begin{array}{l}\text { A novel design method of anthropomorphic } \\
\text { prosthetic hands for reproducing human hand } \\
\text { grasping }\end{array}$ & $\begin{array}{l}\text { Huazhong University of } \\
\text { Science and Technology }\end{array}$ & Unsp. & Prosthetic Hand & C, SD & None Listed \\
\hline Goldberg [36] & 2010 & $\begin{array}{l}\text { Integrating Hands On Design Experiences } \\
\text { Into The Curriculum }\end{array}$ & $\begin{array}{l}\text { University of North } \\
\text { Carolina }\end{array}$ & $\mathrm{So} / \mathrm{J} / \mathrm{S}$ & $\begin{array}{l}\text { Bioreactor } \\
\text { vessel }\end{array}$ & C, SD & $\begin{array}{l}\text { Reports; Student } \\
\text { Feedback }\end{array}$ \\
\hline Mellodge [37] & 2009 & $\begin{array}{l}\text { Digital Health: A Sophomore Level } \\
\text { Interdisciplinary Engineering Design Project } \\
\text { Course }\end{array}$ & University of Hartford & So & $\begin{array}{l}\text { Digital Health } \\
\text { Monitoring } \\
\text { System }\end{array}$ & C, SD & $\begin{array}{l}\text { Presentations; Report; } \\
\text { Peer/Instructor } \\
\text { Evaluations; Survey }\end{array}$ \\
\hline
\end{tabular}




\begin{tabular}{|c|c|c|c|c|c|c|c|}
\hline First Author & Year & Title & Affiliated Institution & $\begin{array}{l}\text { Course } \\
\text { Level }\end{array}$ & $\begin{array}{l}\text { Technical } \\
\text { Area }\end{array}$ & $\begin{array}{l}\text { Emphasis } \\
\text { Area }\end{array}$ & Assessment Method(s) \\
\hline Tranquillo [38] & 2007 & $\begin{array}{l}\text { A Project Driven Approach To Biomedical } \\
\text { Signals And Systems }\end{array}$ & Bucknell University & $\mathrm{J}$ & $\begin{array}{l}\text { Signals and } \\
\text { Systems }\end{array}$ & C, SD & Lab Notebook; Survey \\
\hline Harrison [39] & 2011 & $\begin{array}{l}\text { Wireless Neural/EMG Telemetry Systems for } \\
\text { Small Freely Moving Animals }\end{array}$ & University of Utah & Unsp & $\begin{array}{l}\text { Neural/EMG } \\
\text { Telemetry } \\
\text { System }\end{array}$ & C, SD & None Listed \\
\hline Haase [40] & 2018 & $\begin{array}{l}\text { Modeling and Design: a Hands-on } \\
\text { Introduction to Biomedical Engineering }\end{array}$ & $\begin{array}{l}\text { Johns Hopkins } \\
\text { University }\end{array}$ & $\mathrm{F}$ & Various & C, SD & $\begin{array}{l}\text { Survey; Student } \\
\text { Feedback }\end{array}$ \\
\hline Yao [41] & 2005 & $\begin{array}{l}\text { Stimulating Student Learning with a Novel } \\
\text { "In-House" Pulse Oximeter Design }\end{array}$ & Kansas State University & $\mathrm{J} / \mathrm{S}$ & Pulse Oximeter & C, SD & None Listed \\
\hline Baura [42] & 2019 & $\begin{array}{l}\text { Building a Functional Cardiograph Over Four } \\
\text { Semesters: Part } 2 \text { - Programming a } \\
\text { Microcontroller }\end{array}$ & $\begin{array}{l}\text { Loyola University } \\
\text { Chicago }\end{array}$ & $\mathrm{F}$ to $\mathrm{S}$ & Cardiograph & C, SD & Pre/Post Surveys \\
\hline Baura [43] & 2018 & $\begin{array}{l}\text { Work in Progress: Building a Functional } \\
\text { Cardiograph Over Four Semesters }\end{array}$ & $\begin{array}{l}\text { Loyola University } \\
\text { Chicago }\end{array}$ & $\mathrm{F}$ to $\mathrm{S}$ & Cardiograph & C, SD & Pre/Post Surveys \\
\hline Bhatti [44] & 2010 & $\begin{array}{l}\text { The Coding Of Sound By A Cochlear } \\
\text { Prosthesis: An Introductory Signal Processing } \\
\text { Lab }\end{array}$ & $\begin{array}{l}\text { Georgia Institute of } \\
\text { Technology }\end{array}$ & So/J/S & $\begin{array}{l}\text { Cochlear } \\
\text { Implant Signal } \\
\text { Processor }\end{array}$ & C, SD & $\begin{array}{l}\text { Pre-Labs; Lab Reports; } \\
\text { Survey }\end{array}$ \\
\hline Qian [45] & 2016 & $\begin{array}{l}\text { Brain-Region-Specific Organoids Using Mini } \\
\text { bioreactors for Modeling ZIKV Exposure }\end{array}$ & $\begin{array}{l}\text { Johns Hopkins } \\
\text { University }\end{array}$ & Unsp & Bioreactor & $\mathrm{C}, \mathrm{SD}, \mathrm{T}$ & None Listed \\
\hline Farrell [46] & 2014 & $\begin{array}{l}\text { Organ-izing the Engineering Curriculum with } \\
\text { Biomedically Related Learning Modules }\end{array}$ & Rowan University & $\mathrm{F} / \mathrm{So} / \mathrm{J} / \mathrm{S}$ & $\begin{array}{l}\text { Artificial } \\
\text { Organs }\end{array}$ & $\mathrm{C}, \mathrm{SD}, \mathrm{T}$ & $\begin{array}{l}\text { Quizzes; Survey; } \\
\text { Evaluation }\end{array}$ \\
\hline King [47] & 2002 & $\begin{array}{l}\text { Freshman Biomedical Engineering Design } \\
\text { Projects: What Can Be Done? }\end{array}$ & Vanderbilt University & $\mathrm{F}$ & Various & C, SD, T & None Listed \\
\hline Bazil [48] & 2006 & $\begin{array}{l}\text { Bioinstrumentation Instruction Through } \\
\text { Hybrid Wet/Circuit Laboratory Activities }\end{array}$ & Purdue University & $\mathrm{J}$ & Various & $\mathrm{C}, \mathrm{T}$ & $\begin{array}{l}\text { Survey; Pre/Post-Lab } \\
\text { Exercises }\end{array}$ \\
\hline Bedenbaugh [49] & 2010 & $\begin{array}{l}\text { A Team Based Nerve Cuff Simulation Project } \\
\text { In A Third Year Foundations Of Biomedical } \\
\text { Engineering Course }\end{array}$ & East Carolina University & $\mathrm{J}$ & $\begin{array}{l}\text { Nerve Cuff } \\
\text { Simulation }\end{array}$ & $\mathrm{C}, \mathrm{T}$ & $\begin{array}{l}\text { Time Reports; Self } \\
\text { Assessments; Factual } \\
\text { Questions }\end{array}$ \\
\hline Kyle [50] & 2016 & $\begin{array}{l}\text { Bioinstrumentation: A Project-Based } \\
\text { Engineering Course }\end{array}$ & Columbia University & $\mathrm{J} / \mathrm{S}$ & $\begin{array}{l}\text { Cardiac } \\
\text { Pacemaker }\end{array}$ & SD & $\begin{array}{l}\text { Labs; Midterms; } \\
\text { Pre/Post/Online Surveys }\end{array}$ \\
\hline Atasoy [51] & 2018 & $\begin{array}{l}\text { Biomechanical Design of an } \\
\text { Anthropomorphic Prosthetic Hand }\end{array}$ & Boğaziçi University & Unsp. & Prosthetic Hand & SD & None Listed \\
\hline Jones $[52]$ & 2018 & $\begin{array}{l}\text { Development of an Undergraduate Control } \\
\text { Engineering Design Project: PID Control of } \\
\text { Blood Glucose Levels in Type } 1 \text { Diabetes } \\
\text { Mellitus Subjects }\end{array}$ & Zhejiang University & $\mathrm{J}$ & $\begin{array}{l}\text { Glucose } \\
\text { Monitor }\end{array}$ & SD & None Listed \\
\hline
\end{tabular}




\begin{tabular}{|c|c|c|c|c|c|c|c|}
\hline First Author & Year & Title & Affiliated Institution & $\begin{array}{l}\text { Course } \\
\text { Level }\end{array}$ & $\begin{array}{l}\text { Technical } \\
\text { Area }\end{array}$ & $\begin{array}{l}\text { Emphasis } \\
\text { Area }\end{array}$ & Assessment Method(s) \\
\hline $\begin{array}{l}\text { Supakitamonphan } \\
\text { [53] }\end{array}$ & 2015 & $\begin{array}{l}\text { Electric prosthetic hand activated using two- } \\
\text { channel surface electromyography }\end{array}$ & Rangsit University & Unsp. & Prosthetic Hand & SD & None Listed \\
\hline Opuszynski [54] & 2009 & $\begin{array}{l}\text { Experiential learning in an undergraduate } \\
\text { biomeasurement course: Heart-rate meter }\end{array}$ & $\begin{array}{l}\text { University of Rhode } \\
\text { Island }\end{array}$ & $\mathrm{F} / \mathrm{So} / \mathrm{J} / \mathrm{S}$ & $\begin{array}{l}\text { Heart-Rate } \\
\text { Meter }\end{array}$ & SD & None Listed \\
\hline Tamayo [55] & 2010 & $\begin{array}{l}\text { Microcontroller based pulse oximeter for } \\
\text { undergraduate capstone design }\end{array}$ & $\begin{array}{l}\text { University of Rhode } \\
\text { Island }\end{array}$ & $\mathrm{S}$ & Pulse Oximeter & SD & None Listed \\
\hline Breau [56] & 2005 & $\begin{array}{l}\text { The Neuron Emulator: an undergraduate } \\
\text { Biomedical Engineering design project }\end{array}$ & $\begin{array}{l}\text { University of Rhode } \\
\text { Island }\end{array}$ & $\mathrm{F} / \mathrm{So} / \mathrm{J} / \mathrm{S}$ & $\begin{array}{l}\text { Neuron } \\
\text { Emulator }\end{array}$ & SD & Personal Assessment \\
\hline Long [57] & 2014 & $\begin{array}{l}\text { A design project based approach to teaching } \\
\text { undergraduate instrumentation }\end{array}$ & University of Auckland & $\mathrm{F} / \mathrm{So} / \mathrm{J} / \mathrm{S}$ & $\begin{array}{l}\text { Sleep Apnea } \\
\text { Device }\end{array}$ & SD & $\begin{array}{l}\text { Final Exam; Design } \\
\text { Reports }\end{array}$ \\
\hline Constant [58] & 2015 & $\begin{array}{l}\text { Pulseband: A hands-on tutorial on how to } \\
\text { design a smart wristband to monitor heart-rate }\end{array}$ & $\begin{array}{l}\text { University of Rhode } \\
\text { Island }\end{array}$ & Unsp. & PulseBand & SD & None Listed \\
\hline Bohorquez [59] & 2019 & $\begin{array}{l}\text { Board 1: Introduction to Design Thinking and } \\
\text { Human Centered Design in the Biomedical } \\
\text { Engineering Freshman Year }\end{array}$ & University of Miami & $\mathrm{F}$ & Various & SD & Survey \\
\hline Lai [39] & 2019 & $\begin{array}{l}\text { Board 7: Work in Progress: Approaches to } \\
\text { Introduce Biomedical Engineering Design to a } \\
\text { Class with Diverse STEM Backgrounds }\end{array}$ & $\begin{array}{l}\text { Carnegie Mellon } \\
\text { University }\end{array}$ & HS & Various & SD & Survey \\
\hline Silver-Thorn [61] & 2002 & $\begin{array}{l}\text { A rehabilitation engineering course for } \\
\text { biomedical engineers }\end{array}$ & Marquette University & $\mathrm{S}$ & $\begin{array}{l}\text { Prosthetics/Orth } \\
\text { otics }\end{array}$ & SD & $\begin{array}{l}\text { Quizzes; Exam; Paper; } \\
\text { Survey }\end{array}$ \\
\hline Zeng [62] & 2009 & $\begin{array}{l}\text { Exploration on Undergraduate Curriculum } \\
\text { Reform of Hospital-Oriented Biomedical } \\
\text { Engineering Major }\end{array}$ & $\begin{array}{l}\text { Wenzhou Medical } \\
\text { College }\end{array}$ & $\mathrm{F} / \mathrm{So} / \mathrm{J} / \mathrm{S}$ & $\begin{array}{l}\text { Hospital } \\
\text { Devices }\end{array}$ & SD & None Listed \\
\hline Nagurney [63] & 2007 & The evolution of a bioinstrumentation course & University of Hartford & $\mathrm{S}$ & $\begin{array}{l}\text { ECG, } \\
\text { Pacemaker }\end{array}$ & SD & $\begin{array}{l}\text { Assignments; Labs; Final } \\
\text { Exam; Student Interviews }\end{array}$ \\
\hline $\mathrm{Yu}[64]$ & 2009 & $\begin{array}{l}\text { Towards integrative learning in biomedical } \\
\text { engineering: A project course on } \\
\text { electrocardiogram monitor design }\end{array}$ & $\begin{array}{l}\text { The University of Hong } \\
\text { Kong }\end{array}$ & So & ECG & SD & $\begin{array}{l}\text { Surveys; Participation; } \\
\text { Demonstrations; Final } \\
\text { Exam; Report }\end{array}$ \\
\hline Chan [65] & 2011 & $\begin{array}{l}\text { Integrative learning through the design of an } \\
\text { electrocardiogram acquisition system }\end{array}$ & Carleton University & $\mathrm{J} / \mathrm{S}$ & ECG & SD & Demonstrations; Reports \\
\hline Aldridge [66] & 2017 & $\begin{array}{l}\text { Autonomous robot design and build: novel } \\
\text { hands-on experience for undergraduate } \\
\text { students }\end{array}$ & $\begin{array}{l}\text { Grand Valley State } \\
\text { University }\end{array}$ & So & Robot & SD & None Listed \\
\hline Fletcher [67] & 2014 & $\begin{array}{l}\text { Design and clinical feasibility of personal } \\
\text { wearable monitor for measurement of activity } \\
\text { and environmental exposure }\end{array}$ & $\begin{array}{l}\text { Massachusetts Institute } \\
\text { of Technology }\end{array}$ & Unsp. & $\begin{array}{l}\text { Wearable } \\
\text { Monitor }\end{array}$ & SD & None Listed \\
\hline
\end{tabular}




\begin{tabular}{|c|c|c|c|c|c|c|c|}
\hline First Author & Year & Title & Affiliated Institution & $\begin{array}{l}\text { Course } \\
\text { Level }\end{array}$ & $\begin{array}{l}\text { Technical } \\
\text { Area }\end{array}$ & $\begin{array}{l}\text { Emphasis } \\
\text { Area }\end{array}$ & Assessment Method(s) \\
\hline Jeong [68] & 2017 & $\begin{array}{l}\text { NFC-enabled, tattoo-like stretchable biosensor } \\
\text { manufactured by "cut-and-paste" method }\end{array}$ & $\begin{array}{l}\text { University of Texas at } \\
\text { Austin }\end{array}$ & Unsp. & $\begin{array}{l}\text { Tattoo-like } \\
\text { Biosensor }\end{array}$ & $\mathrm{SD}$ & None Listed \\
\hline Xiong [69] & 2016 & $\begin{array}{l}\text { Design and Implementation of an } \\
\text { Anthropomorphic Hand for Replicating } \\
\text { Human Grasping Functions }\end{array}$ & $\begin{array}{l}\text { Huazhong University of } \\
\text { Science and Technology }\end{array}$ & Unsp. & Prosthetic Hand & $\mathrm{SD}$ & None Listed \\
\hline Castles [70] & 2016 & $\begin{array}{l}\text { Flipping the Microprocessors Classroom: A } \\
\text { Comparative Assessment }\end{array}$ & East Carolina University & Unsp. & Microprocessor & SD & Final Exam; Survey \\
\hline Hill [71] & 2016 & $\begin{array}{l}\text { A Multidisciplinary Undergraduate } \\
\text { Nanotechnology Education Program with } \\
\text { Integrated Laboratory Experience and } \\
\text { Outreach Activities }\end{array}$ & $\begin{array}{l}\text { Mississippi State } \\
\text { University }\end{array}$ & $\mathrm{F}$ & $\begin{array}{l}\text { Nanotechnolog } \\
\mathrm{y}\end{array}$ & SD & None Listed \\
\hline Farrell [72] & 2016 & $\begin{array}{l}\text { An Adaptable and Transferrable Project Based } \\
\text { on a Heart-lung Machine Design Challenge }\end{array}$ & Rowan University & $\begin{array}{l}\mathrm{HS} / \mathrm{F} / \mathrm{So} \\
/ \mathrm{J} / \mathrm{S}\end{array}$ & $\begin{array}{l}\text { Heart-Lung } \\
\text { Machine }\end{array}$ & SD & Survey; Design Report \\
\hline Yildiz [73] & 2016 & $\begin{array}{l}\text { Design and Development of a Non-Contact } \\
\text { Thermography Device for Equine Research }\end{array}$ & $\begin{array}{l}\text { Sam Houston State } \\
\text { University }\end{array}$ & Unsp. & $\begin{array}{l}\text { Thermography } \\
\text { Device }\end{array}$ & SD & None Listed \\
\hline Ruddy [74] & 2016 & $\begin{array}{l}\text { Work in Progress: The Consumer } \\
\text { Breathalyzer as a Model Design Project in } \\
\text { Introductory Instrumentation }\end{array}$ & University of Auckland & So & Breathalyzer & SD & $\begin{array}{l}\text { Lab Notebooks; Group } \\
\text { Reports; Final Report; } \\
\text { Presentation }\end{array}$ \\
\hline Choi [75] & 2016 & $\begin{array}{l}\text { Work in Progress: The Incorporation of } \\
\text { Hands-On, Team-Based Design Challenges in } \\
\text { a Large Enrollment Introductory Biomedical } \\
\text { Engineering Course }\end{array}$ & $\begin{array}{l}\text { University of California } \\
\text { - Davis }\end{array}$ & $\mathrm{F}$ & Various & SD & Survey \\
\hline Joo [76] & 2016 & $\begin{array}{l}\text { Work in Progress: Hands-On Practice of } \\
\text { Implant Surgery Using Artificial Bone in } \\
\text { Design Course }\end{array}$ & $\begin{array}{l}\text { Robert Morris } \\
\text { University }\end{array}$ & $\mathrm{S}$ & Medical Device & SD & Survey \\
\hline Schmedlen [77] & 2016 & $\begin{array}{l}\text { The Medical Device Sandbox: A Creative } \\
\text { Learning Experience for BME Students and } \\
\text { Medical Learners }\end{array}$ & University of Michigan & $\mathrm{F} / \mathrm{So} / \mathrm{J} / \mathrm{S}$ & Various & $\mathrm{SD}$ & $\begin{array}{l}\text { Survey; Focus Groups; } \\
\text { Pre-Test }\end{array}$ \\
\hline Gibson [78] & 2002 & $\begin{array}{l}\text { Capstone Design Projects: Helping the } \\
\text { Disabled }\end{array}$ & $\begin{array}{l}\text { Rose-Hulman Institute } \\
\text { of Technology }\end{array}$ & S & Various & $\mathrm{SD}$ & None Listed \\
\hline Bernitt [79] & 2016 & $\begin{array}{l}\text { A Low-Cost Bio-Imaging and Incubation } \\
\text { System }\end{array}$ & University of Bremen & Unsp. & $\begin{array}{l}\text { Bio-Imaging } \\
\text { and Incubation } \\
\text { System }\end{array}$ & SD & None Listed \\
\hline Grier [80] & 2018 & $\begin{array}{l}\text { A low-cost do-it-yourself microscope kit for } \\
\text { hands-on science education }\end{array}$ & N/A & Unsp. & $\begin{array}{l}\text { Microscope } \\
\text { Imaging }\end{array}$ & SD & $\begin{array}{l}\text { Unstructured feedback; } \\
\text { surveys }\end{array}$ \\
\hline Jani [81] & 2017 & $\begin{array}{l}\text { Design of a Low-power, Low-cost ECG \& } \\
\text { EMG Sensor for Wearable Biometric and }\end{array}$ & $\begin{array}{l}\text { Dhirubhai Ambani } \\
\text { Institute of Information }\end{array}$ & Unsp. & $\begin{array}{l}\text { ECG and EMG } \\
\text { Sensor }\end{array}$ & SD & None Listed \\
\hline
\end{tabular}




\begin{tabular}{|c|c|c|c|c|c|c|c|}
\hline First Author & Year & Title & Affiliated Institution & $\begin{array}{l}\text { Course } \\
\text { Level }\end{array}$ & $\begin{array}{l}\text { Technical } \\
\text { Area }\end{array}$ & $\begin{array}{l}\text { Emphasis } \\
\text { Area }\end{array}$ & Assessment Method(s) \\
\hline & & Medical Application & $\begin{array}{l}\text { and Communication } \\
\text { Technology }\end{array}$ & & & & \\
\hline Pimentel [82] & 2014 & A \$5 Smart Blood Pressure System & University of Oxford & Unsp. & $\begin{array}{l}\text { Blood Pressure } \\
\text { System }\end{array}$ & $\mathrm{SD}$ & None Listed \\
\hline Casey [83] & 2014 & $\begin{array}{l}\text { A cost-efficient spring-powered dermatome to } \\
\text { treat skin trauma }\end{array}$ & $\begin{array}{l}\text { Massachusetts Institute of } \\
\text { Technology }\end{array}$ & f Unsp. & Dermatome & SD & None Listed \\
\hline Cruden [84] & 2018 & Frugal Skin Graft Expansion Device & Santa Clara University & Unsp. & $\begin{array}{l}\text { Skin Graft } \\
\text { Expansion } \\
\text { Device }\end{array}$ & SD & None Listed \\
\hline Wolf $[85]$ & 2009 & $\begin{array}{l}\text { On Setting-Up a Portable Low-Cost Real- } \\
\text { Time Control System for Research and } \\
\text { Teaching with Application to Bioprocess pH } \\
\text { Control }\end{array}$ & University of Heidelberg & Unsp. & $\begin{array}{l}\text { Real-Time } \\
\text { Control System }\end{array}$ & SD & None Listed \\
\hline Fuller [86] & 2004 & $\begin{array}{l}\text { Portable, Low-Cost Medical Ultrasound } \\
\text { Device Prototype }\end{array}$ & University of Virginia & Unsp. & $\begin{array}{l}\text { Ultrasound } \\
\text { Device }\end{array}$ & $\mathrm{SD}$ & None Listed \\
\hline $\operatorname{Kim}[87]$ & 2013 & $\begin{array}{l}\text { Smartphone-based Portable Ultrasound } \\
\text { Imaging System: A Primary Result }\end{array}$ & Sogang University & Unsp. & $\begin{array}{l}\text { Ultrasound } \\
\text { Imaging } \\
\text { System }\end{array}$ & SD & None Listed \\
\hline Pan $[88]$ & 2004 & $\begin{array}{l}\text { Mechatronic experiments course design: a } \\
\text { myoelectric controlled partial-hand prosthesis } \\
\text { project }\end{array}$ & $\begin{array}{l}\text { Kuang-Wu Institute of } \\
\text { Technology }\end{array}$ & $\mathrm{S}$ & Prosthetic Hand & $\mathrm{SD}$ & $\begin{array}{l}\text { Observations; Student } \\
\text { Interviews; Survey }\end{array}$ \\
\hline Warren [89] & 2016 & $\begin{array}{l}\text { Design projects motivated and informed by } \\
\text { the needs of severely disabled autistic children }\end{array}$ & Kansas State University & $\mathrm{S}$ & Various & SD & None Listed \\
\hline Gale $[90]$ & 2019 & $\begin{array}{l}\text { Work in Progress: Multidisciplinary, } \\
\text { Vertically Integrated Course on 3-D Printed } \\
\text { Biomedical Devices }\end{array}$ & New York University & $\mathrm{F} / \mathrm{So} / \mathrm{J} / \mathrm{S}$ & $\begin{array}{l}\text { 3D Printed } \\
\text { Orthotics }\end{array}$ & SD & $\begin{array}{l}\text { Lab Notebook; Survey; } \\
\text { Student Feedback }\end{array}$ \\
\hline Carlson [91] & 2019 & $\begin{array}{l}\text { An Improved Cellphone-based Wearable } \\
\text { Electrocardiograph Project for a Biomedical } \\
\text { Instrumentation Course Sequence }\end{array}$ & Kansas State University & $\mathrm{S}$ & $\begin{array}{l}\text { Cellphone- } \\
\text { Based } \\
\text { Wearable ECG }\end{array}$ & SD & Pre/Post Surveys \\
\hline Carlsen [92] & 2018 & $\begin{array}{l}\text { Project-based Learning: Engaging Biomedical } \\
\text { Engineering Sophomores Through a } \\
\text { Collaborative Vein-finder Device Project with } \\
\text { Nursing }\end{array}$ & $\begin{array}{l}\text { Robert Morris } \\
\text { University }\end{array}$ & So & $\begin{array}{l}\text { Vein Finder } \\
\text { Device }\end{array}$ & $\mathrm{SD}$ & $\begin{array}{l}\text { Rubric; Peer Evaluation; } \\
\text { Surveys; Exams; } \\
\text { Assignments }\end{array}$ \\
\hline Rust [93] & 2013 & $\begin{array}{l}\text { Engaging Undergraduate Biomedical } \\
\text { Engineering Students in Lab on a Chip } \\
\text { Research through a Course-Based Project }\end{array}$ & $\begin{array}{l}\text { Western New England } \\
\text { University }\end{array}$ & $\mathrm{J} / \mathrm{S}$ & $\begin{array}{l}\text { Microfluidic } \\
\text { Device }\end{array}$ & $\mathrm{SD}$ & $\begin{array}{l}\text { Pre/Post Surveys; } \\
\text { Surveys }\end{array}$ \\
\hline Warren [94] & 2016 & Student Proposals for Design Projects to Aid & Kansas State University & $\mathrm{S}$ & Various & SD & Rubrics \\
\hline
\end{tabular}




\begin{tabular}{|c|c|c|c|c|c|c|c|}
\hline First Author & Year & Title & Affiliated Institution & $\begin{array}{l}\text { Course } \\
\text { Level }\end{array}$ & $\begin{array}{l}\text { Technical } \\
\text { Area }\end{array}$ & $\begin{array}{l}\text { Emphasis } \\
\text { Area }\end{array}$ & Assessment Method(s) \\
\hline & & Children with Severe Disabilities & & & & & \\
\hline Warren [95] & 2018 & $\begin{array}{l}\text { Board } 79 \text { : A Wearable Electrocardiograph as } \\
\text { a Means to Combine Measurement and } \\
\text { Makerspace Concepts in a Biomedical } \\
\text { Instrumentation Course Sequence }\end{array}$ & Kansas State University & $\mathrm{S}$ & Wearable ECG & SD & $\begin{array}{l}\text { Rubric, Surveys, Open- } \\
\text { Ended Questions }\end{array}$ \\
\hline Allen [96] & 2018 & $\begin{array}{l}\text { Patient Centered Design in Undergraduate } \\
\text { Biomedical Engineering }\end{array}$ & University of Virginia & $\mathrm{J} / \mathrm{S}$ & $\begin{array}{l}\text { Patient- } \\
\text { Centered } \\
\text { Design }\end{array}$ & SD & $\begin{array}{l}\text { Student Feedback; } \\
\text { Objectives Met; } \\
\text { Completeness }\end{array}$ \\
\hline Cezeaux [97] & 2007 & $\begin{array}{l}\text { Design For The Disabled As An } \\
\text { Interdisciplinary Laboratory Project }\end{array}$ & $\begin{array}{l}\text { Western New England } \\
\text { College }\end{array}$ & $\mathrm{S}$ & $\begin{array}{l}\text { Tape cutting } \\
\text { Device }\end{array}$ & SD & $\begin{array}{l}\text { Final Report; Device } \\
\text { Design; Peer Evaluation }\end{array}$ \\
\hline Nagel [98] & 2012 & $\begin{array}{l}\text { On a Client-Centered, Sophomore Design } \\
\text { Course Sequence }\end{array}$ & $\begin{array}{l}\text { James Madison } \\
\text { University }\end{array}$ & So & $\begin{array}{l}\text { Pedaled } \\
\text { Vehicle }\end{array}$ & SD & $\begin{array}{l}\text { Project, Course, and } \\
\text { Performance Evaluations }\end{array}$ \\
\hline Caplan [99] & 2017 & $\begin{array}{l}\text { Curiosity and Connections (Entrepreneurial } \\
\text { Mindset) in BME Sophomore Design }\end{array}$ & Arizona State University & So & $\begin{array}{l}\text { Glucose } \\
\text { Monitor }\end{array}$ & SD & None Listed \\
\hline Caplan [100] & 2017 & $\begin{array}{l}\text { Sophomore Design Course on Virtual } \\
\text { Prototyping }\end{array}$ & Arizona State University & So & $\begin{array}{l}\text { Glucuse } \\
\text { Monitor Device }\end{array}$ & SD & $\begin{array}{l}\text { Pre/Post Surveys; } \\
\text { Rubrics }\end{array}$ \\
\hline Reid [101] & 2011 & $\begin{array}{l}\text { An Innovative Interdisciplinary Student } \\
\text { Project: Engineering and Nursing }\end{array}$ & $\begin{array}{l}\text { Ohio Northern } \\
\text { University }\end{array}$ & $\mathrm{F}$ & $\begin{array}{l}\text { Fetal Heartbeat } \\
\text { Simulator }\end{array}$ & SD & $\begin{array}{l}\text { Whether Redesigns } \\
\text { Worked; Student } \\
\text { Testimonials }\end{array}$ \\
\hline Bucks [102] & 2015 & $\begin{array}{l}\text { Engineering Your Community: Experiences } \\
\text { of Students in a Service-Learning Engineering } \\
\text { Design Course }\end{array}$ & University of Cincinnati & $\mathrm{F} / \mathrm{So} / \mathrm{J} / \mathrm{S}$ & Various & SD & $\begin{array}{l}\text { Course Evaluations; } \\
\text { Student Reflections }\end{array}$ \\
\hline Lai-Yuen [103] & 2009 & $\begin{array}{l}\text { Integrating Real World Medical Device } \\
\text { Projects Into Manufacturing Education }\end{array}$ & $\begin{array}{l}\text { University of South } \\
\text { Florida }\end{array}$ & So/J & Various & SD & Project Evaluation Forms \\
\hline Cavanagh [104] & 2017 & $\begin{array}{l}\text { Diseases, Devices, and Patients: Exposing } \\
\text { BME Students to the Patient Experience }\end{array}$ & Bucknell University & $\mathrm{J} / \mathrm{S}$ & Various & SD & $\begin{array}{l}\text { Course/Instructor } \\
\text { Evaluations; Instructor } \\
\text { Observations; Student } \\
\text { Reflections }\end{array}$ \\
\hline Lasher [105] & 2010 & $\begin{array}{l}\text { Design and characterization of a modified T- } \\
\text { flask bioreactor for continuous monitoring of } \\
\text { engineered tissue stiffness }\end{array}$ & University of Utah & Unsp. & Bioreactors & $\mathrm{SD}, \mathrm{T}$ & None Listed \\
\hline Rajan [106] & 2018 & $\begin{array}{l}\text { A Portable Live-Cell Imaging System With an } \\
\text { Invert-Upright-Convertible Architecture and a } \\
\text { Mini-Bioreactor for Long-Term Simultaneous } \\
\text { Cell Imaging, Chemical Sensing, and } \\
\text { Electrophysiological Recording }\end{array}$ & $\begin{array}{l}\text { Tampere University of } \\
\text { Technology }\end{array}$ & Unsp. & $\begin{array}{l}\text { Bioreactor, } \\
\text { Live Cell } \\
\text { Imaging } \\
\text { System }\end{array}$ & $\mathrm{SD}, \mathrm{T}$ & None Listed \\
\hline
\end{tabular}




\begin{tabular}{|c|c|c|c|c|c|c|c|}
\hline First Author & Year & Title & Affiliated Institution & $\begin{array}{l}\text { Course } \\
\text { Level }\end{array}$ & $\begin{array}{l}\text { Technical } \\
\text { Area }\end{array}$ & $\begin{array}{l}\text { Emphasis } \\
\text { Area }\end{array}$ & Assessment Method(s) \\
\hline Bhattarai [107] & 2015 & $\begin{array}{l}\text { Enhancing Undergraduate Students' Learning } \\
\text { and Research Experiences through Hands-on } \\
\text { Experiments in Bio-nanoengineering }\end{array}$ & $\begin{array}{l}\text { North Carolina A\&T } \\
\text { State University }\end{array}$ & $\mathrm{So} / \mathrm{J}$ & $\begin{array}{l}\text { Bio-nano } \\
\text { Devices and } \\
\text { Systems }\end{array}$ & $\mathrm{SD}, \mathrm{T}$ & $\begin{array}{l}\text { Content Assessment; } \\
\text { Survey; Focus Groups }\end{array}$ \\
\hline Nimunkar [108] & 2014 & $\begin{array}{l}\text { Using Guided Design Instruction to Motivate } \\
\text { BME Sophomore Students to Learn } \\
\text { Multidisciplinary Engineering Skills }\end{array}$ & $\begin{array}{l}\text { University of } \\
\text { Wisconsin, Madison }\end{array}$ & So & Bioreactors & $\mathrm{SD}, \mathrm{T}$ & $\begin{array}{l}\text { Self/Peer Evaluations; } \\
\text { Quizzes; Rubrics }\end{array}$ \\
\hline Comolli [109] & 2010 & $\begin{array}{l}\text { The Artificial Kidney: Investigating Current } \\
\text { Dialysis Methods As A Freshman Design } \\
\text { Project }\end{array}$ & Villanova University & $\mathrm{F}$ & $\begin{array}{l}\text { Artificial } \\
\text { Kidney Filter }\end{array}$ & $\mathrm{SD}, \mathrm{T}$ & $\begin{array}{l}\text { Pre/Post Surveys; } \\
\text { Quizzes; Design Reports }\end{array}$ \\
\hline Henkel [110] & 2015 & $\begin{array}{l}\text { Teaching bioprocess engineering to } \\
\text { undergraduates: Multidisciplinary hands-on } \\
\text { training in a one-week practical course }\end{array}$ & $\begin{array}{l}\text { University of } \\
\text { Hohenheim }\end{array}$ & So & Bioreactors & $\mathrm{T}$ & $\begin{array}{l}\text { Pre/Post Lab Questions; } \\
\text { Exams }\end{array}$ \\
\hline Vernengo [111] & 2014 & $\begin{array}{l}\text { Undergraduate Laboratory Experiment } \\
\text { TEACHING FUNDAMENTAL CONCEPTS } \\
\text { OF RHEOLOGY In Context of Sickle Cell } \\
\text { Anemia }\end{array}$ & Rowan University & $\mathrm{F}$ & $\begin{array}{l}\text { Artificial Blood } \\
\text { Construction } \\
\text { and Analysis }\end{array}$ & $\mathrm{T}$ & Pre/Post Quizzes \\
\hline Saterbak [112] & 2002 & $\begin{array}{l}\text { Laboratory Courses Focused On Tissue } \\
\text { Engineering Applications }\end{array}$ & Rice University & $\mathrm{J} / \mathrm{S}$ & $\begin{array}{l}\text { Tissue } \\
\text { Engineering } \\
\text { Experiments }\end{array}$ & $\mathrm{T}$ & $\begin{array}{l}\text { Surveys; Student } \\
\text { Interviews }\end{array}$ \\
\hline Saterbak [113] & 2001 & $\begin{array}{l}\text { Development Of A Novel Foundation Course } \\
\text { For Biomedical Engineering Curriculum }\end{array}$ & Rice University & So & Organ Model & $\mathrm{T}$ & Mid/Post Surveys \\
\hline Childers [114] & 2019 & $\begin{array}{l}\text { A Gold Nanoparticle-based Lab Experiment } \\
\text { Sequence to Enhance Learning in Biomedical } \\
\text { Nanotechnology at the Undergraduate Level }\end{array}$ & University of Oklahoma & $\mathrm{J}$ & $\begin{array}{l}\text { Gold } \\
\text { Nanoparticles }\end{array}$ & $\mathrm{T}$ & $\begin{array}{l}\text { Self/Instructor } \\
\text { Evaluations; Final Exam }\end{array}$ \\
\hline
\end{tabular}

